\title{
Surface Composition Evolution of Bimetallic Alloys under Reaction
}

\section{Conditions}

Jun Meng, ${ }^{1,2}$ Beien Zhu, ${ }^{1,3, *}{ }^{*}$ Yi Gao $^{1,3, *}$

1. Shanghai Institute of Applied Physics, Chinese Academy of Sciences, Shanghai 201800 China

2. University of Chinese Academy of Sciences, Beijing 100049 China

3. Zhangjiang Laboratory, Shanghai Advanced Research Institute, Chinese Academy of Sciences, Shanghai 201210 China

Email: zhubeien@zjlab.org.cn, gaoyi@zjlab.org.cn 


\section{Content}

Table S1. Calculated data of the segregation energy under vacuum $E_{\text {seg }}$, the binding energy of one $\mathrm{CO}$ molecule at the isolated surface solute atom $B E^{\text {sol }}$ and on the clean host surface $B E^{\text {host }}$, and the lateral interaction term $\mathrm{z} w$ of the $\mathrm{CO}$ molecules on the host surface.

Figure S1. The slab models for the calculation of (a) $E_{\text {surf }}^{\text {sol }}$, (b) $E_{\text {bulk }}^{\text {sol }}$, (c) $B E^{\text {host }}$, and (d) $B E^{\text {sol }}$.

Figure S2. Coverage of CO on the host sites $\left(\theta_{\text {host }}\right)$ and on the solute sites $\left(\theta_{\text {sol }}\right)$ changing with the temperature from $300 \mathrm{~K}$ to $1200 \mathrm{~K}$ under $10^{4} \mathrm{~Pa} \mathrm{CO}$.

Figure S3. Comparisons of the $E_{s e g}$ in vacuum, gas adsorption effect term $E_{\theta}$, adsorbates lateral interaction effect term $E_{l}$, and the environmental segregation energy $E_{\text {eseg }}$ at different temperature under $10^{4} \mathrm{~Pa} \mathrm{CO}$.

Figure S4. The environmental segregation energy of Rh solute in Pd host $E_{\text {eseg }}^{R h / P d}$ changing with the NO coverage on $\mathrm{Rh}$ at $573 \mathrm{~K}$. The $\mathrm{Rh}$ surface segregation trend is labeled by color.

Figure S5. Contour plots of the environmental segregation energy $E_{\text {eseg }}$ of 72 combinations of 9 transition metals according to the temperature and $\mathrm{CO}$ pressure, classified as five groups. The segregation trend is donated by color based on the value of $E_{\text {eseg }}$, and the corresponding value is labeled with the colorbar.

Figure S6. The environmental segregation energy $E_{\text {eseg }}$ of the 72 bimetallic alloys with the changing temperature under $100 \mathrm{~Pa} \mathrm{CO}$, compared with the segregation energy $E_{\text {seg }}$ under UHV. The segregation trend is donated by color based on the value of $E_{\text {eseg }}$, and the corresponding value is labeled with the colorbar.

Figure S7. The environmental segregation energy $E_{\text {eseg }}$ of the 72 bimetallic alloys with the changing temperature under $10^{5} \mathrm{PaCO}$, compared with the segregation energy $E_{\text {seg }}$ under UHV. The segregation trend is donated by color based on the value of $E_{\text {eseg }}$, and the corresponding value is labeled with the colorbar.

Figure S8. Contour plots of the CO coverage on host $\left(\theta_{\text {host }}\right)$ and solute $\left(\theta_{\text {sol }}\right)$ of 72 combinations of 9 transition metals according to the temperature and $\mathrm{CO}$ pressure. The value of the coverage is denoted by colors, and the corresponding value is labeled with the colorbar. The phase graph of $\theta_{\text {host }}$ is titled by Metal host, and the phase graph of $\theta_{\text {sol }}$ is titled by Solute in Host. 
Table S1. Calculated data of the segregation energy under vacuum $E_{\text {seg }}$, the binding energy of one $\mathrm{CO}$ molecule at the isolated surface solute atom $B E^{\text {sol }}$ and on the clean host surface $B E^{\text {host }}$, and the lateral interaction term $\mathrm{zw}$ of the $\mathrm{CO}$ molecules on the host surface.

\begin{tabular}{|c|c|c|c|c|}
\hline "Solute/Host & $\overline{\boldsymbol{E}_{\boldsymbol{s e g}}(\mathrm{eV})}$ & $\bar{c} \boldsymbol{B} \boldsymbol{E}^{\text {sol }}(\mathrm{eV})$ & $\begin{array}{l}\boldsymbol{B} \boldsymbol{E}^{\text {host }}(\mathrm{eV}) \\
\end{array}$ & $\bar{z} \boldsymbol{z w}(\mathrm{eV})$ \\
\hline $\mathrm{Cu} / \mathrm{Au}$ & 0.36 & -0.29 & -0.22 & -0.48 \\
\hline $\mathrm{Pt} / \mathrm{Au}$ & 0.32 & -1.21 & -0.22 & -0.48 \\
\hline $\mathrm{Pd} / \mathrm{Au}$ & 0.38 & -0.76 & -0.22 & -0.48 \\
\hline $\mathrm{Rh} / \mathrm{Au}$ & 0.55 & -1.76 & -0.22 & -0.48 \\
\hline $\mathrm{Co} / \mathrm{Au}$ & 0.36 & -1.74 & -0.22 & -0.48 \\
\hline $\mathrm{Ni} / \mathrm{Au}$ & 0.36 & -1.17 & -0.22 & -0.48 \\
\hline $\mathrm{Ag} / \mathrm{Au}$ & 0.12 & -0.15 & -0.22 & -0.48 \\
\hline $\mathrm{Ir} / \mathrm{Au}$ & 0.51 & -2.26 & -0.22 & -0.48 \\
\hline $\mathrm{Au} / \mathrm{Cu}$ & -0.58 & -0.20 & -0.47 & -1.20 \\
\hline $\mathrm{Pt} / \mathrm{Cu}$ & -0.12 & -1.14 & -0.47 & -1.20 \\
\hline $\mathrm{Pd} / \mathrm{Cu}$ & -0.15 & -0.80 & -0.47 & -1.20 \\
\hline $\mathrm{Ni} / \mathrm{Cu}$ & 0.22 & -1.32 & -0.47 & -1.20 \\
\hline $\mathrm{Rh} / \mathrm{Cu}$ & 0.15 & -1.73 & -0.47 & -1.20 \\
\hline $\mathrm{Ag} / \mathrm{Cu}$ & -0.57 & -0.17 & -0.47 & -1.20 \\
\hline $\mathrm{Co} / \mathrm{Cu}$ & 0.38 & -1.83 & -0.47 & -1.20 \\
\hline $\mathrm{Ir} / \mathrm{Cu}$ & 0.24 & -2.13 & -0.47 & -1.20 \\
\hline $\mathrm{Au} / \mathrm{Ag}$ & -0.05 & -0.21 & -0.08 & -0.2 \\
\hline $\mathrm{Cu} / \mathrm{Ag}$ & 0.12 & -0.41 & -0.08 & -0.2 \\
\hline $\mathrm{Pt} / \mathrm{Ag}$ & 0.21 & -1.28 & -0.08 & -0.2 \\
\hline $\mathrm{Ni} / \mathrm{Ag}$ & 0.24 & -1.45 & -0.08 & -0.2 \\
\hline $\mathrm{Co} / \mathrm{Ag}$ & 0.07 & -2.07 & -0.08 & -0.2 \\
\hline $\mathrm{Pd} / \mathrm{Ag}$ & 0.20 & -0.89 & -0.08 & -0.2 \\
\hline $\mathrm{Rh} / \mathrm{Ag}$ & 0.39 & -1.90 & -0.08 & -0.2 \\
\hline $\mathrm{Ir} / \mathrm{Ag}$ & 0.44 & -2.37 & -0.08 & -0.2 \\
\hline $\mathrm{Au} / \mathrm{Pt}$ & -0.57 & -0.19 & -1.48 & -1.14 \\
\hline $\mathrm{Rh} / \mathrm{Pt}$ & 0.39 & -1.70 & -1.48 & -1.14 \\
\hline $\mathrm{Cu} / \mathrm{Pt}$ & 0.40 & -0.29 & -1.48 & -1.14 \\
\hline $\mathrm{Co} / \mathrm{Pt}$ & 0.64 & -1.12 & -1.48 & -1.14 \\
\hline $\mathrm{Ni} / \mathrm{Pt}$ & 0.53 & -1.14 & -1.48 & -1.14 \\
\hline $\mathrm{Pd} / \mathrm{Pt}$ & 0.07 & -0.85 & -1.48 & -1.14 \\
\hline $\mathrm{Ag} / \mathrm{Pt}$ & -0.38 & -0.18 & -1.48 & -1.14 \\
\hline $\mathrm{Ir} / \mathrm{Pt}$ & 0.38 & -2.07 & -1.48 & -1.14 \\
\hline $\mathrm{Au} / \mathrm{Pd}$ & -0.40 & -0.32 & -1.59 & -1.32 \\
\hline $\mathrm{Cu} / \mathrm{Pd}$ & 0.08 & -0.48 & -1.59 & -1.32 \\
\hline $\mathrm{Pt} / \mathrm{Pd}$ & 0.03 & -1.50 & -1.59 & -1.32 \\
\hline $\mathrm{Rh} / \mathrm{Pd}$ & 0.27 & -1.83 & -1.59 & -1.32 \\
\hline $\mathrm{Ir} / \mathrm{Pd}$ & 0.33 & -2.19 & -1.59 & -1.32 \\
\hline $\mathrm{Ni} / \mathrm{Pd}$ & 0.21 & -1.31 & -1.59 & -1.32 \\
\hline $\mathrm{Ag} / \mathrm{Pd}$ & -0.31 & -0.20 & -1.59 & -1.32 \\
\hline
\end{tabular}




\begin{tabular}{ccccc}
\hline $\mathrm{Co} / \mathrm{Pd}$ & -0.49 & -1.88 & -1.59 & -1.32 \\
\hline $\mathrm{Pd} / \mathrm{Rh}$ & -0.48 & -0.88 & -1.62 & -1.08 \\
\hline $\mathrm{Ir} / \mathrm{Rh}$ & 0.13 & -1.85 & -1.62 & -1.08 \\
\hline $\mathrm{Pt} / \mathrm{Rh}$ & -0.36 & -1.24 & -1.62 & -1.08 \\
\hline $\mathrm{Au} / \mathrm{Rh}$ & -1.17 & -0.21 & -1.62 & -1.08 \\
\hline $\mathrm{Ni} / \mathrm{Rh}$ & -0.15 & -1.20 & -1.62 & -1.08 \\
\hline $\mathrm{Cu} / \mathrm{Rh}$ & -0.50 & -0.36 & -1.62 & -1.08 \\
\hline $\mathrm{Ag} / \mathrm{Rh}$ & -1.21 & -0.16 & -1.62 & -1.08 \\
\hline $\mathrm{Co} / \mathrm{Rh}$ & -0.09 & -1.61 & -1.62 & -1.08 \\
\hline $\mathrm{Pt} / \mathrm{Ni}$ & -0.45 & -1.27 & -1.54 & -1.56 \\
\hline $\mathrm{Cu} / \mathrm{Ni}$ & -0.27 & -0.42 & -1.54 & -1.56 \\
\hline $\mathrm{Co} / \mathrm{Ni}$ & 0.14 & -2.04 & -1.54 & -1.56 \\
\hline $\mathrm{Pd} / \mathrm{Ni}$ & -0.56 & -0.92 & -1.54 & -1.56 \\
\hline $\mathrm{Ag} / \mathrm{Ni}$ & -1.19 & -0.23 & -1.54 & -1.56 \\
\hline $\mathrm{Au} / \mathrm{Ni}$ & -1.17 & -0.30 & -1.54 & -1.56 \\
\hline $\mathrm{Rh} / \mathrm{Ni}$ & -0.14 & -1.59 & -1.54 & -1.56 \\
\hline $\mathrm{Sn} / \mathrm{Ni}$ & -1.56 & -0.01 & -1.54 & -1.56 \\
\hline $\mathrm{Ir} / \mathrm{Ni}$ & -0.01 & -1.89 & -1.54 & -1.56 \\
\hline $\mathrm{Rh} / \mathrm{Ir}$ & -0.03 & -1.47 & -1.78 & -1.06 \\
\hline $\mathrm{Pd} / \mathrm{Ir}$ & -0.60 & -0.74 & -1.78 & -1.06 \\
\hline $\mathrm{Pt} / \mathrm{Ir}$ & -0.61 & -1.13 & -1.78 & -1.06 \\
\hline $\mathrm{Ni} / \mathrm{Ir}$ & -0.11 & -1.00 & -1.78 & -1.06 \\
\hline $\mathrm{Co} / \mathrm{Ir}$ & 0.02 & -1.24 & -1.78 & -1.06 \\
\hline $\mathrm{Cu} / \mathrm{Ir}$ & -0.57 & -0.22 & -1.78 & -1.06 \\
\hline $\mathrm{Ag} / \mathrm{Ir}$ & -1.58 & 0.35 & -1.78 & -1.06 \\
\hline $\mathrm{Au} / \mathrm{Ir}$ & -1.64 & 0.41 & -1.78 & -1.06 \\
\hline $\mathrm{Pt} / \mathrm{Co}$ & -0.65 & -1.17 & -1.40 & -2.09 \\
\hline $\mathrm{Ni} / \mathrm{Co}$ & -0.09 & -1.20 & -1.40 & -2.09 \\
\hline $\mathrm{Cu} / \mathrm{Co}$ & -0.39 & -0.45 & -1.40 & -2.09 \\
\hline $\mathrm{Pd} / \mathrm{Co}$ & -0.75 & -0.89 & -1.40 & -2.09 \\
\hline $\mathrm{Rh} / \mathrm{Co}$ & -0.37 & -1.50 & -1.40 & -2.09 \\
\hline $\mathrm{Au} / \mathrm{Co}$ & -1.35 & -0.36 & -1.40 & -2.09 \\
\hline $\mathrm{Ag} / \mathrm{Co}$ & -1.40 & -0.24 & -1.40 & -2.09 \\
\hline $\mathrm{Ir} / \mathrm{Co}$ & -0.21 & -1.80 & -1.40 & -2.09 \\
\hline & & & & \\
\hline
\end{tabular}


(a)

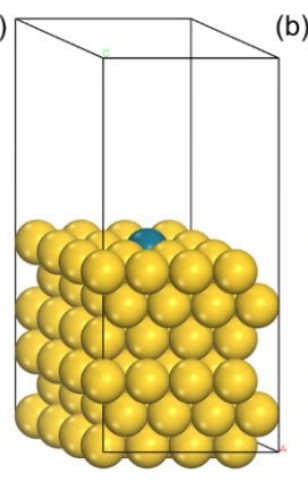

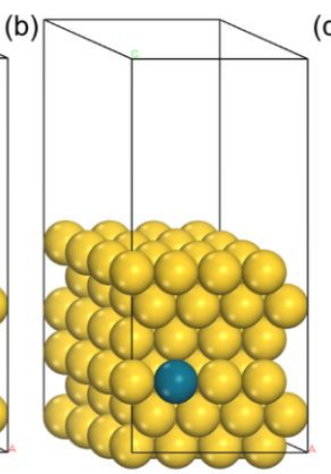
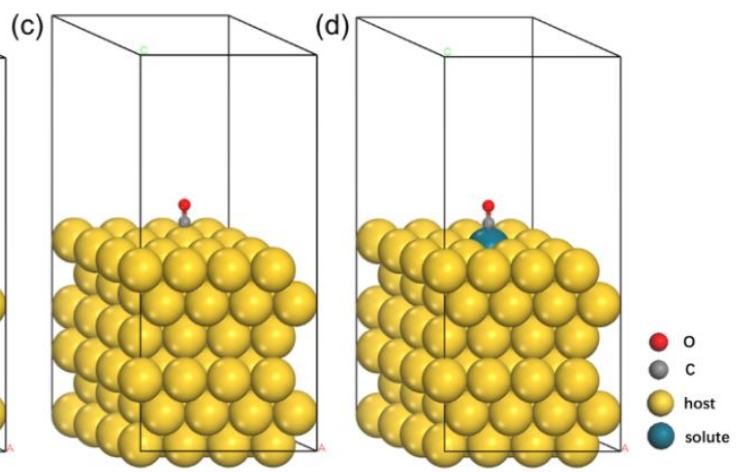

Figure S1. The slab models for the calculation of (a) $E_{\text {surf }}^{\text {sol }}$, (b) $E_{\text {bulk }}^{\text {sol }}$, (c) $B E^{\text {host }}$, and (d) $B E^{\text {sol }}$.

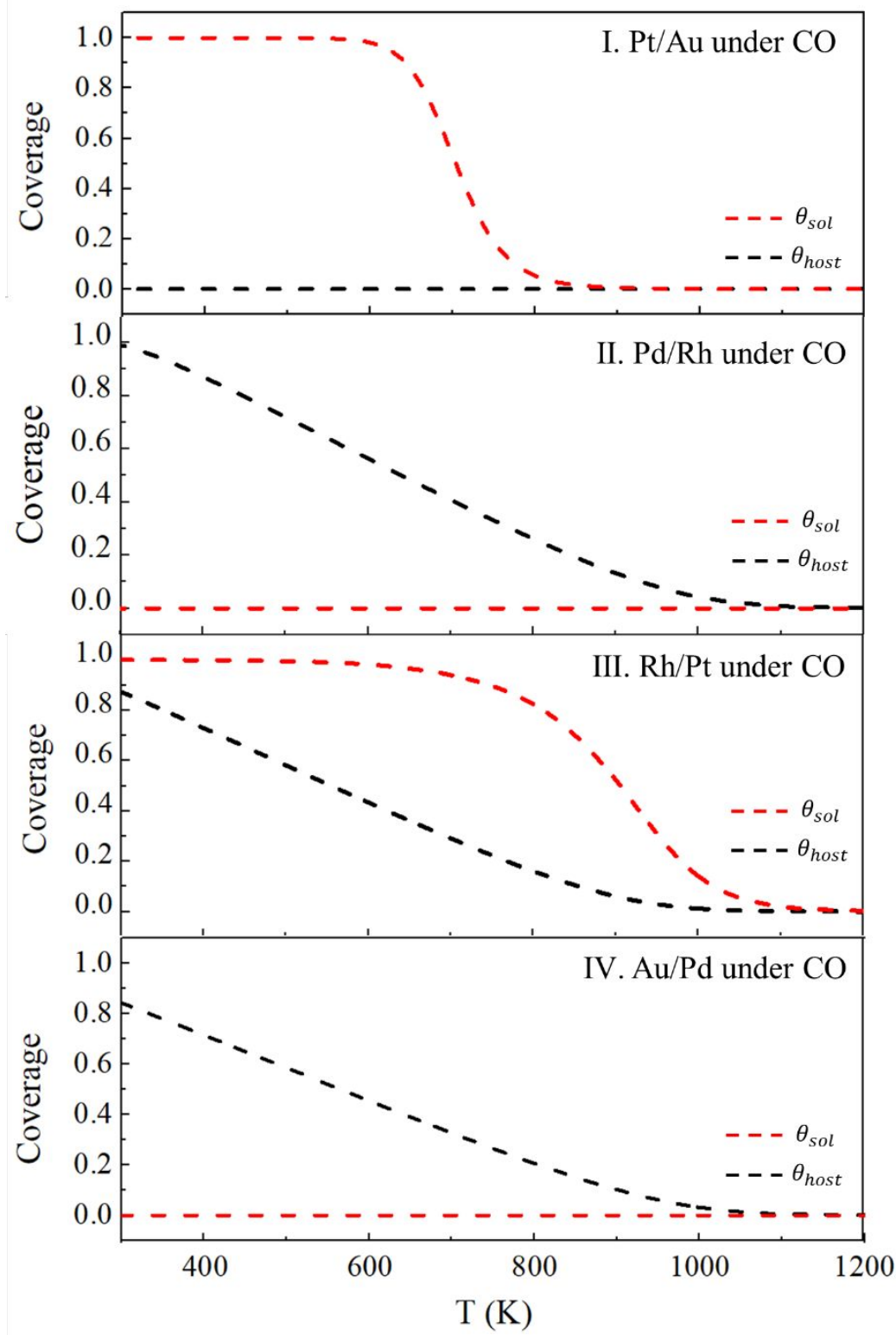

Figure S2. Coverage of CO on the host sites $\left(\theta_{\text {host }}\right)$ and on the solute sites $\left(\theta_{\text {sol }}\right)$ changing with the temperature from $300 \mathrm{~K}$ to $1200 \mathrm{~K}$ under $10^{4} \mathrm{~Pa} \mathrm{CO}$. 

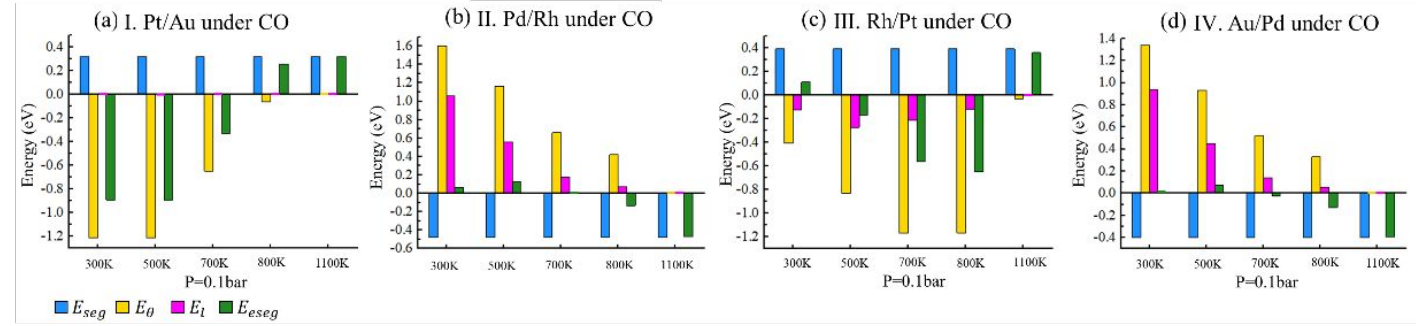

Figure S3. Comparisons of the $E_{\text {seg }}$ in vacuum, gas adsorption effect term $E_{\theta}$, adsorbates lateral interaction effect term $E_{l}$, and the environmental segregation energy $E_{\text {eseg }}$ at different temperature under $10^{4} \mathrm{~Pa} \mathrm{CO}$.

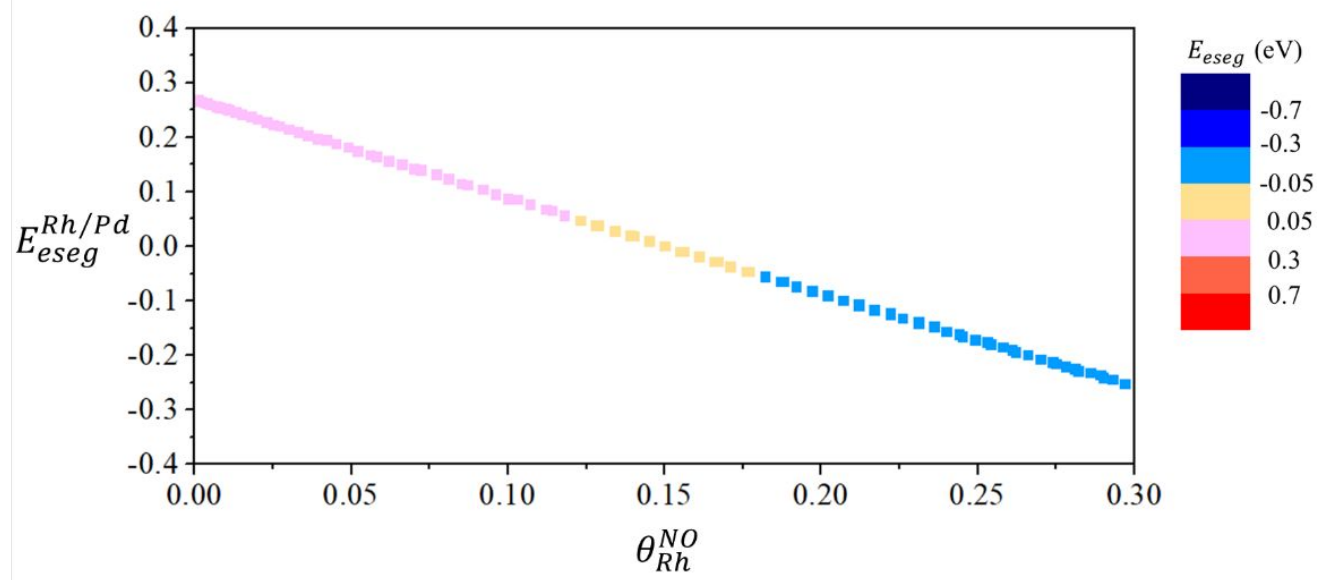

Figure S4. The environmental segregation energy of Rh solute in Pd host $E_{\text {eseg }}^{R h / P d}$ changing with the NO coverage on $\mathrm{Rh}$ at $573 \mathrm{~K}$. The $\mathrm{Rh}$ surface segregation trend is labeled by color. 
Group I
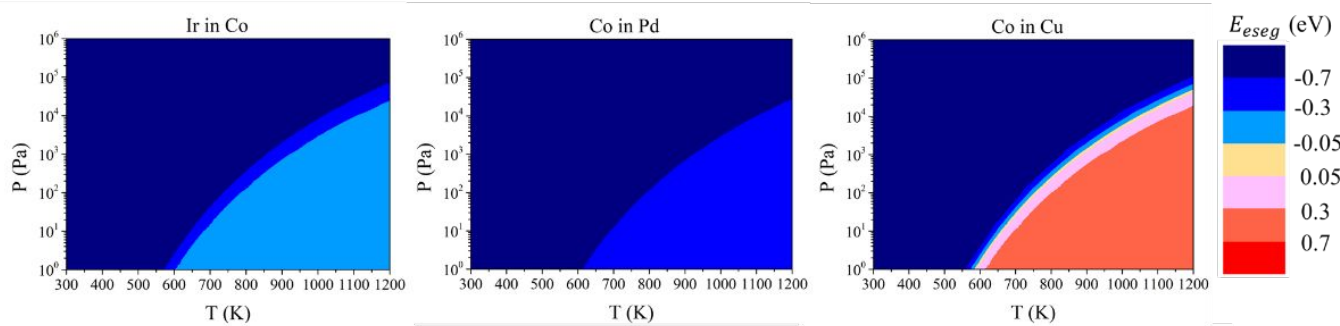

$\mathrm{T}(\mathrm{K})$

$\mathrm{T}(\mathrm{K})$

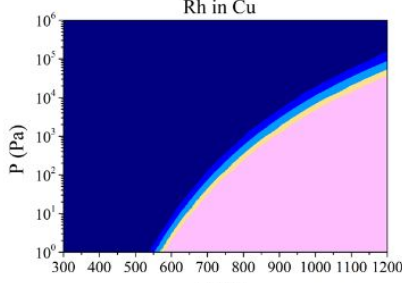

Ir in $\mathrm{Cu}$

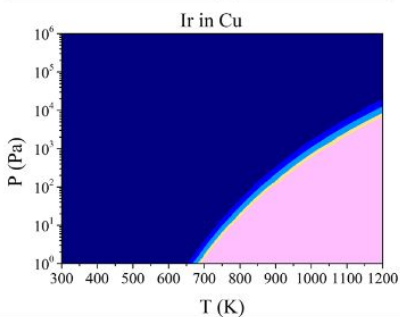

$\mathrm{T}(\mathrm{K})$

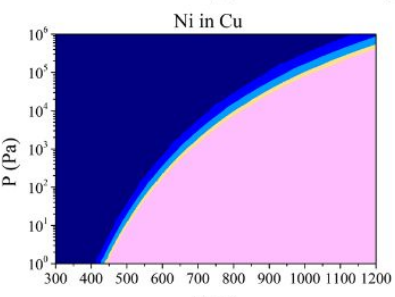

$\mathrm{T}(\mathrm{K})$
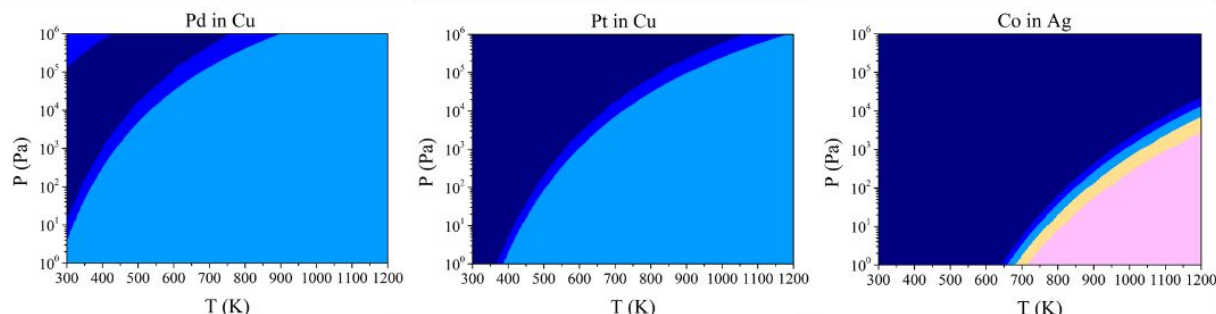

$\mathrm{Rh}$ in $\mathrm{Ag}$
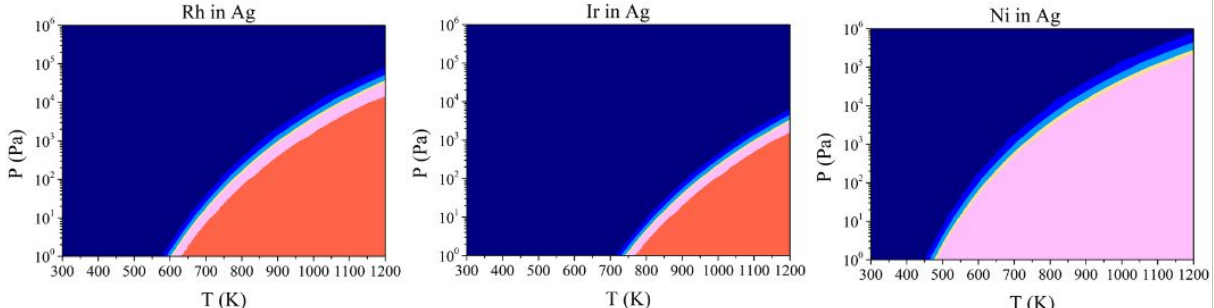

$\mathrm{T}(\mathrm{K})$
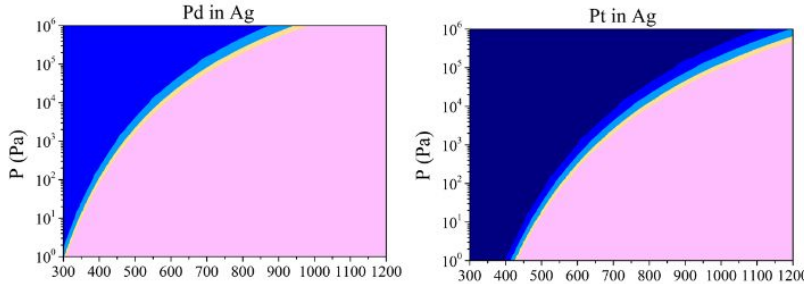

$\mathrm{T}$ (K)

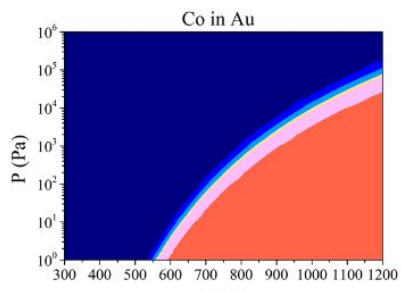

$\mathrm{T}(\mathrm{K})$

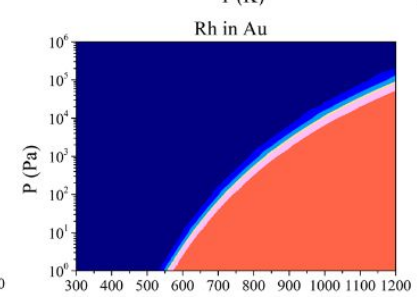

$\mathrm{T}(\mathrm{K})$

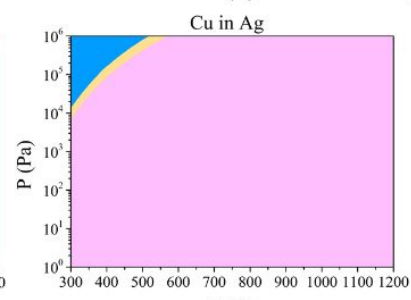

$\mathrm{T}(\mathrm{K})$
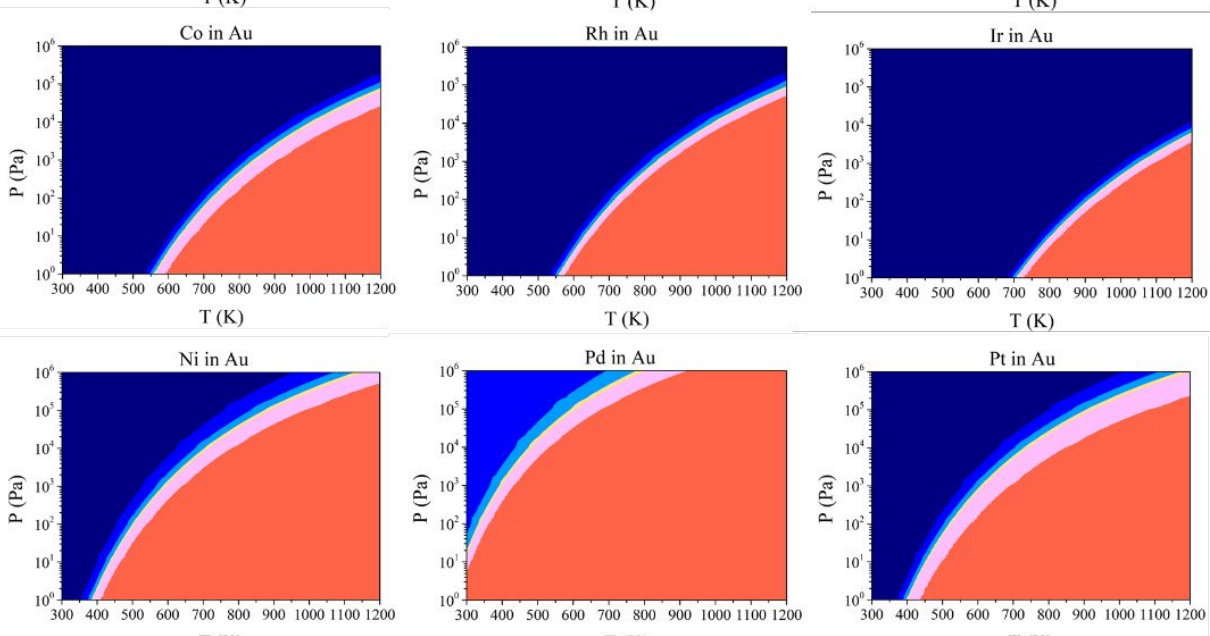

$\mathrm{T}(\mathrm{K})$
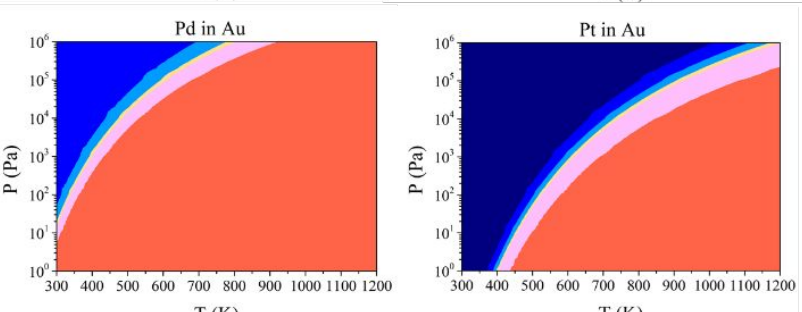

$\mathrm{T}(\mathrm{K})$ 
Group II
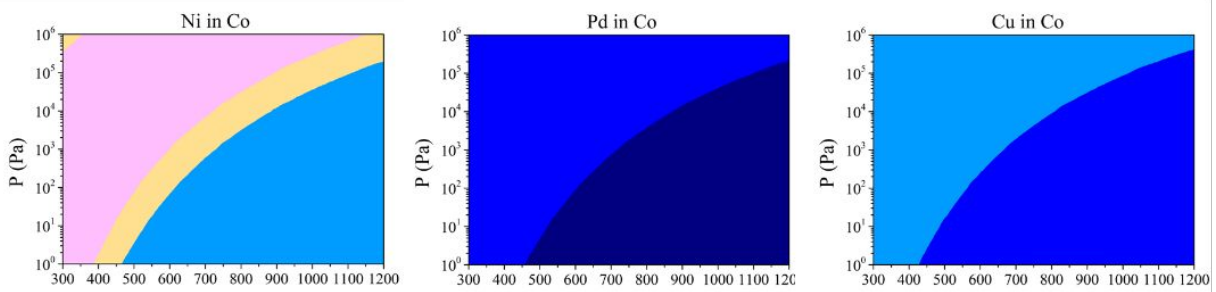

$E_{\text {eseg }}(\mathrm{eV})$

$\mathrm{T}(\mathrm{K})$

$\mathrm{T}(\mathrm{K})$
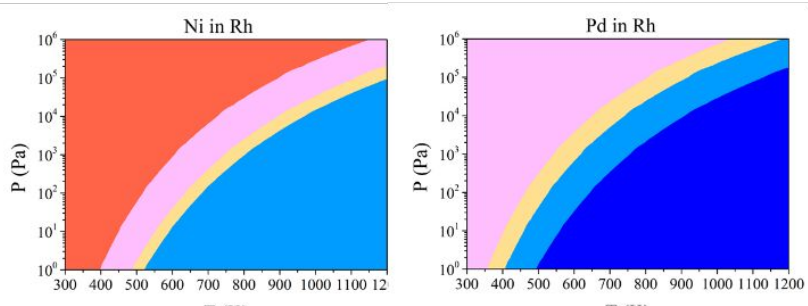

$\mathrm{T}(\mathrm{K})$

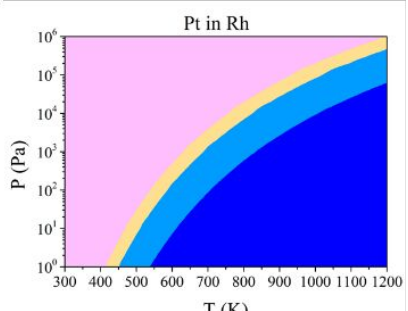

$\mathrm{g}$ in $\mathrm{Rh}$

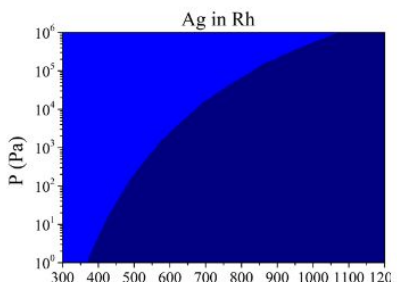

$\mathrm{T}(\mathrm{K})$
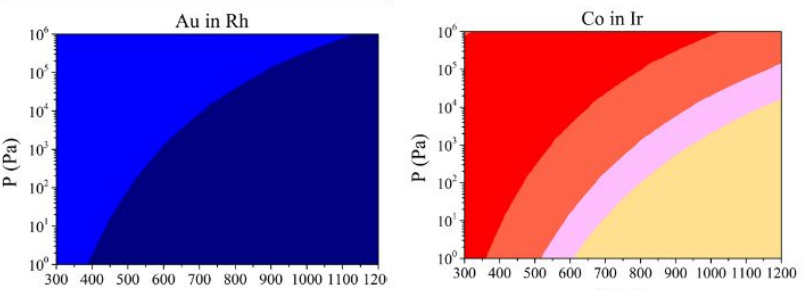

$\mathrm{T}(\mathrm{K})$

$\mathrm{T}(\mathrm{K})$
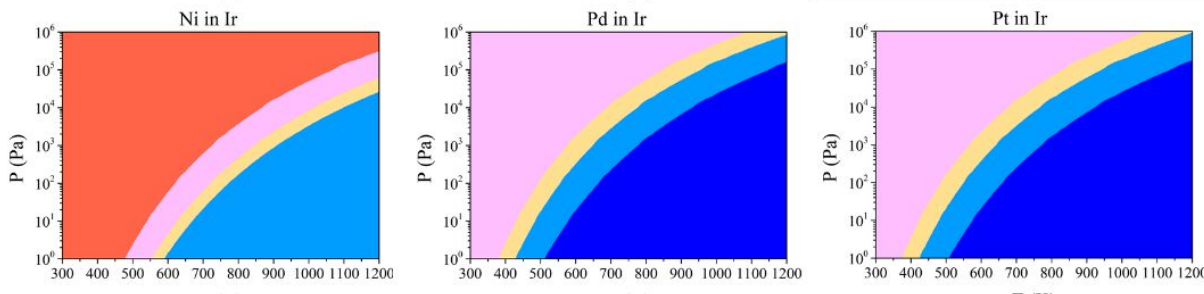

$\mathrm{T}(\mathrm{K})$

$\mathrm{T}(\mathrm{K})$
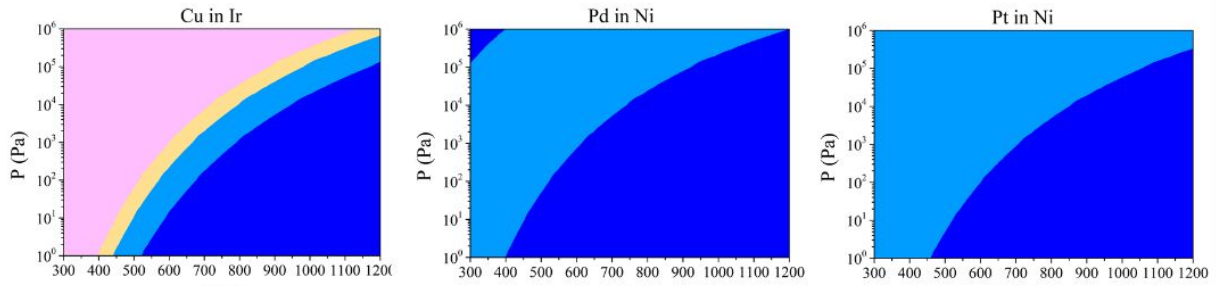

$\mathrm{T}(\mathrm{K})$

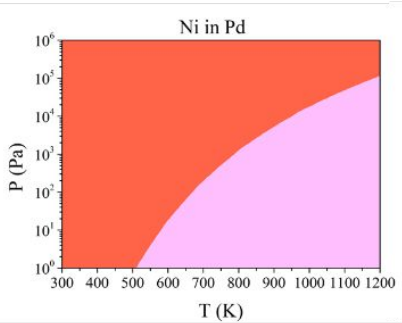

$\mathrm{Cu}$ in $\mathrm{Pd}$

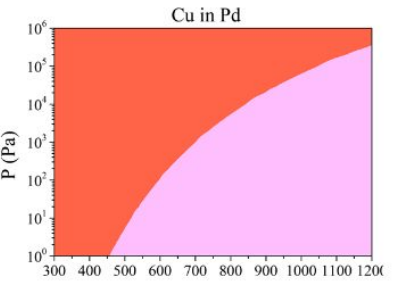

(K)

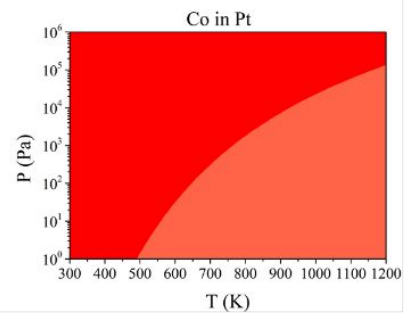

$\mathrm{T}(\mathrm{K})$
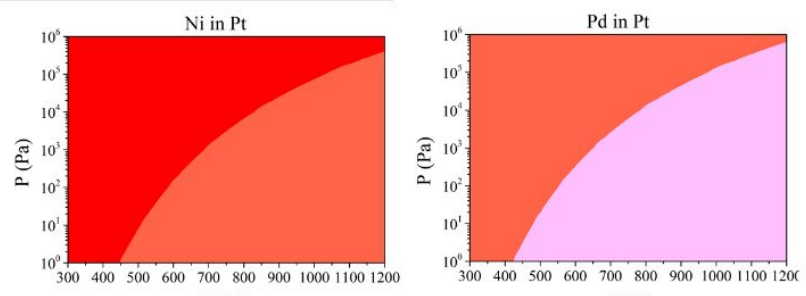

$\mathrm{T}(\mathrm{K})$

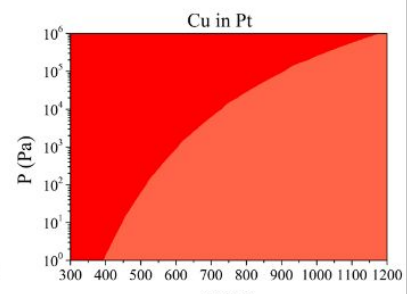

$\mathrm{T}(\mathrm{K})$ 


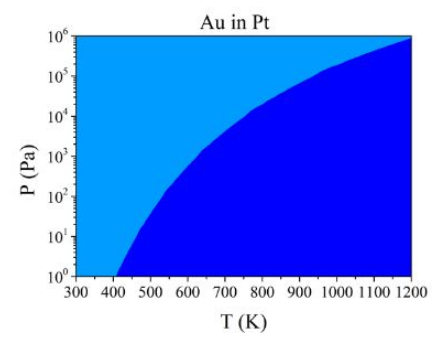

Group III

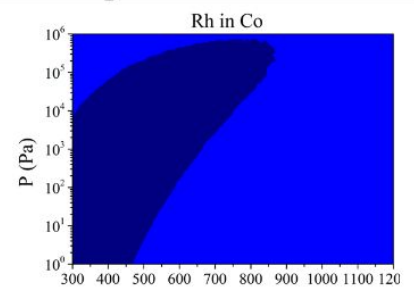

$\mathrm{T}(\mathrm{K})$
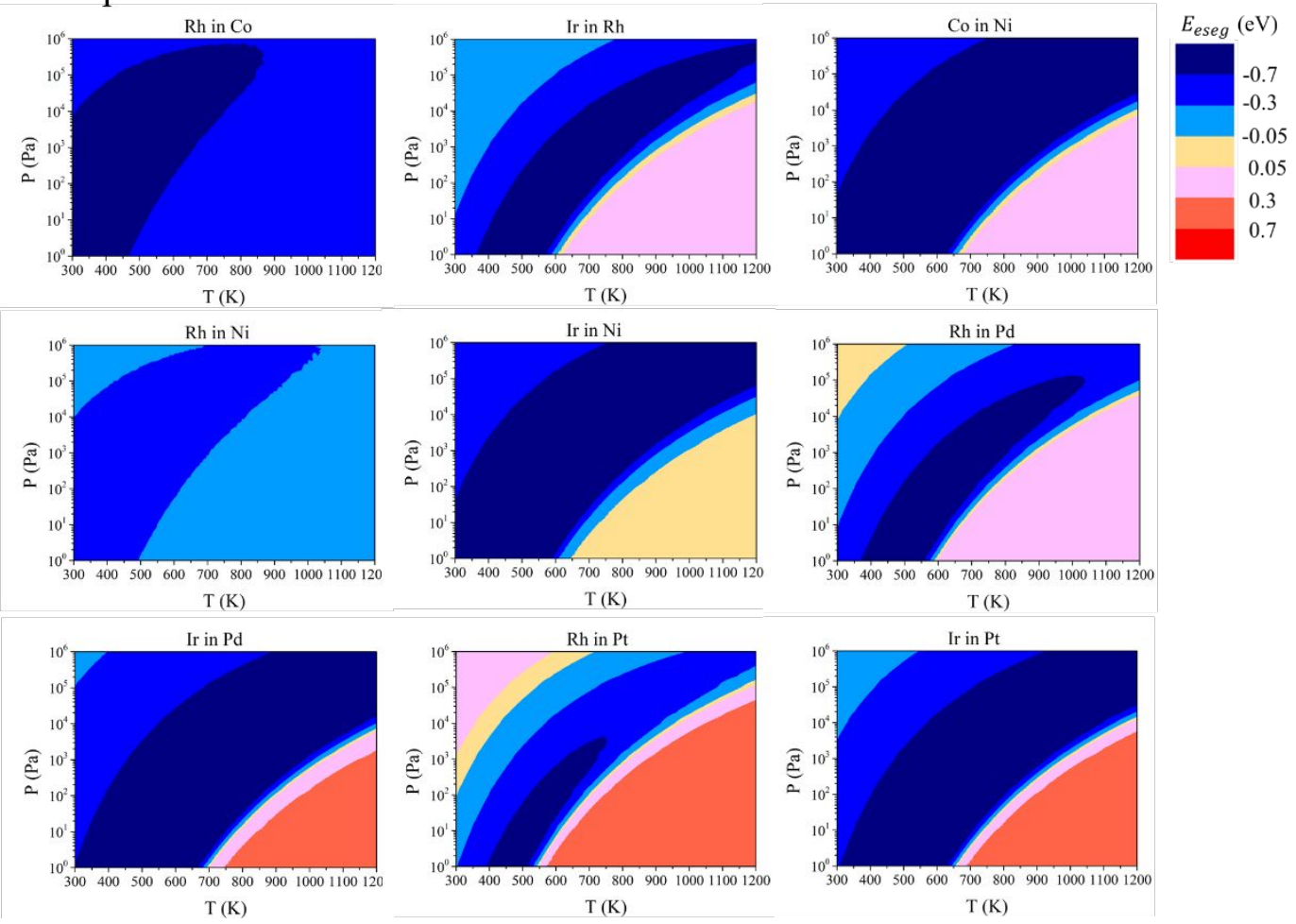


\section{Group IV}

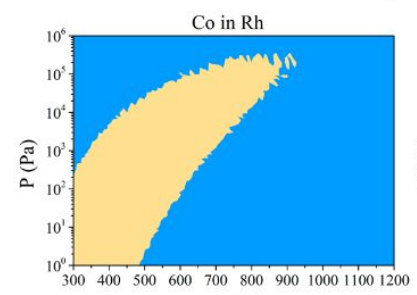

$\mathrm{T}(\mathrm{K})$

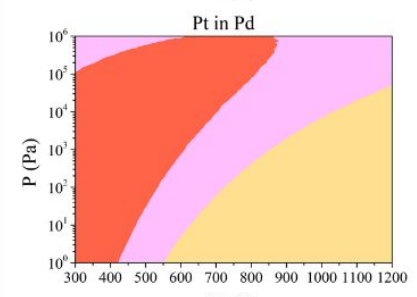

$\mathrm{T}(\mathrm{K})$

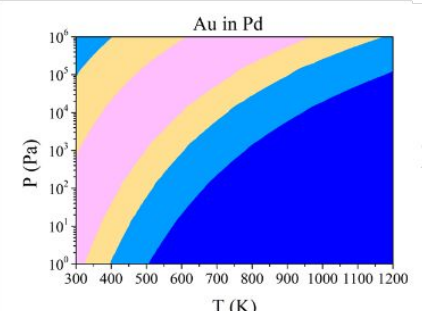

$\mathrm{T}(\mathrm{K})$

\section{Group V}

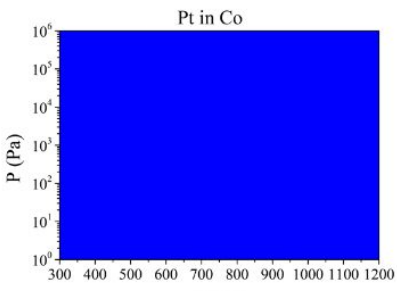

$\mathrm{T}(\mathrm{K})$
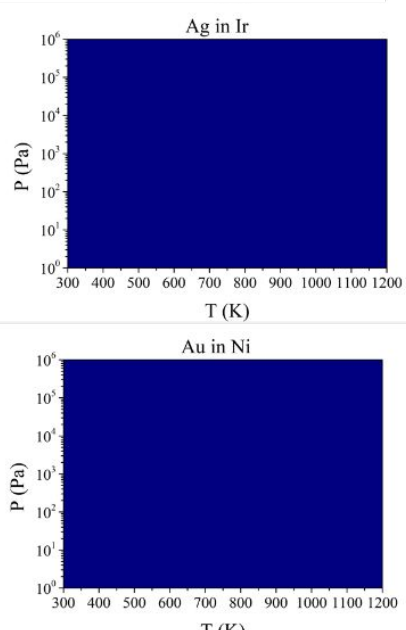

$\mathrm{T}(\mathrm{K})$

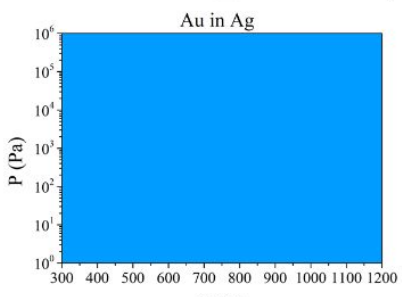

$\mathrm{T}(\mathrm{K})$

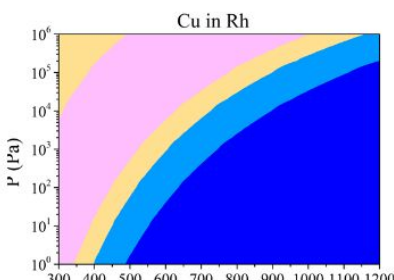

$\mathrm{T}(\mathrm{K})$

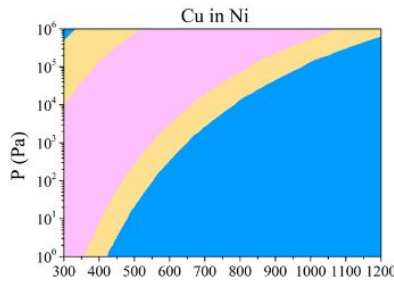

$\mathrm{T}(\mathrm{K})$

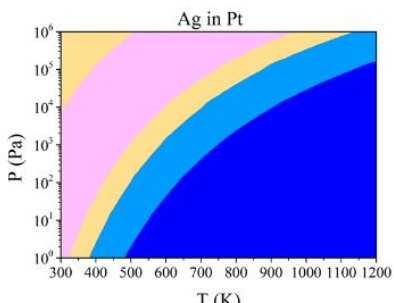

$\mathrm{T}(\mathrm{K})$

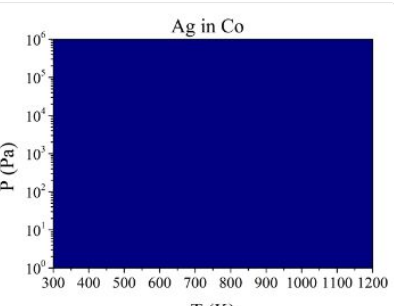

$\mathrm{T}(\mathrm{K})$

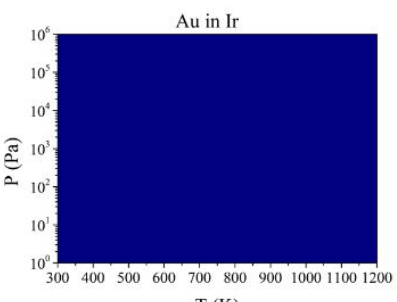

$\mathrm{T}(\mathrm{K})$

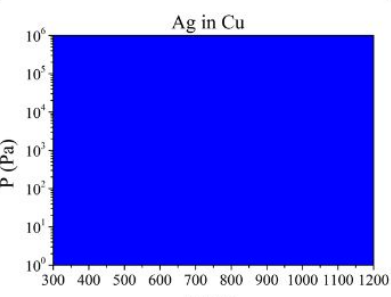

$\mathrm{T}(\mathrm{K})$

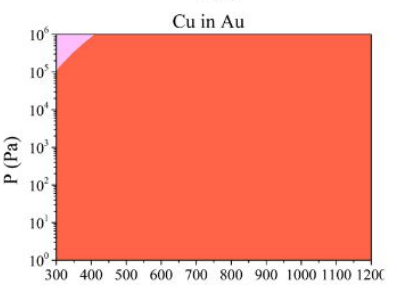

$\mathrm{T}(\mathrm{K})$

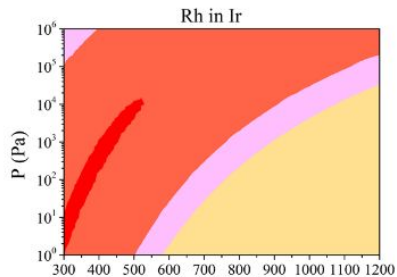

$E_{\text {eseg }}(\mathrm{eV})$

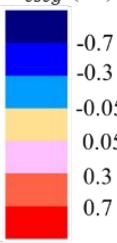

$\mathrm{T}(\mathrm{K})$

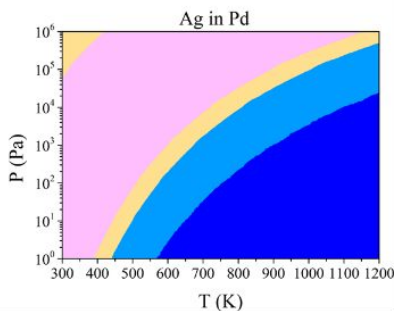

T (K

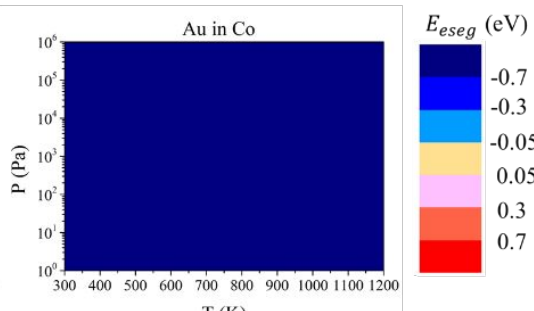

$\mathrm{T}(\mathrm{K})$

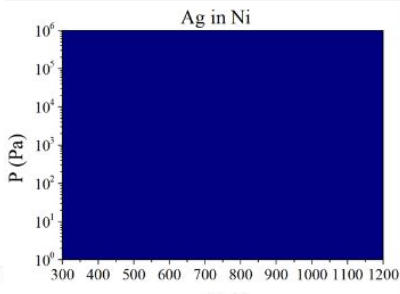

$\mathrm{T}(\mathrm{K})$

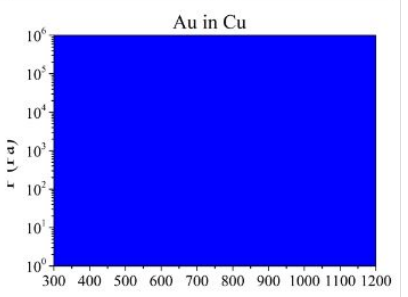

T $/ W$

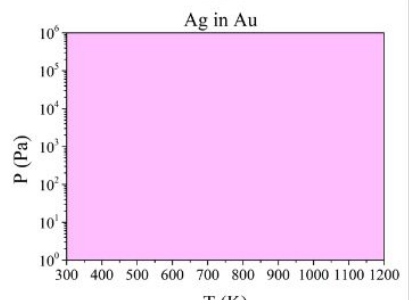

$\mathrm{T}(\mathrm{K})$ 
Figure S5. Contour plots of the environmental segregation energy $E_{\text {eseg }}$ of 72 combinations of 9 transition metals as functions of temperature and $\mathrm{CO}$ pressure, classified into five groups. The segregation trend is donated by color based on the value of $E_{\text {eseg, }}$, as shown in the colorbar. 


$$
\mathrm{P}=10^{5} \mathrm{~Pa}
$$

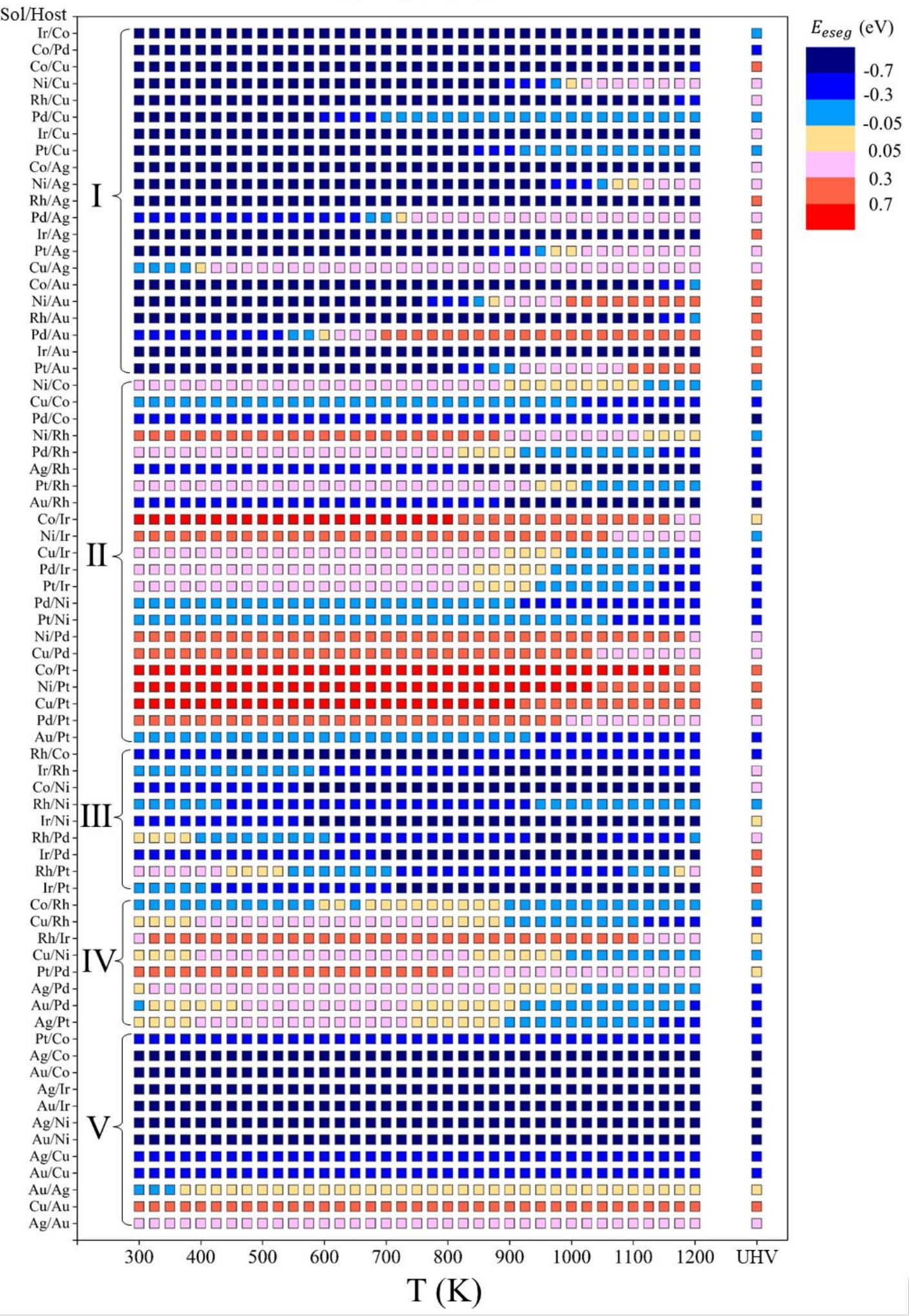

Figure S6. The environmental segregation energy $E_{\text {eseg }}$ of the 72 bimetallic alloys with the changing temperature under $10^{5} \mathrm{PaCO}$, compared with the segregation energy $E_{\text {seg }}$ under UHV. The segregation trend is donated by color based on the value of $E_{\text {eseg }}$, and the corresponding value is labeled with the colorbar. 


$$
\mathrm{P}=100 \mathrm{~Pa}
$$

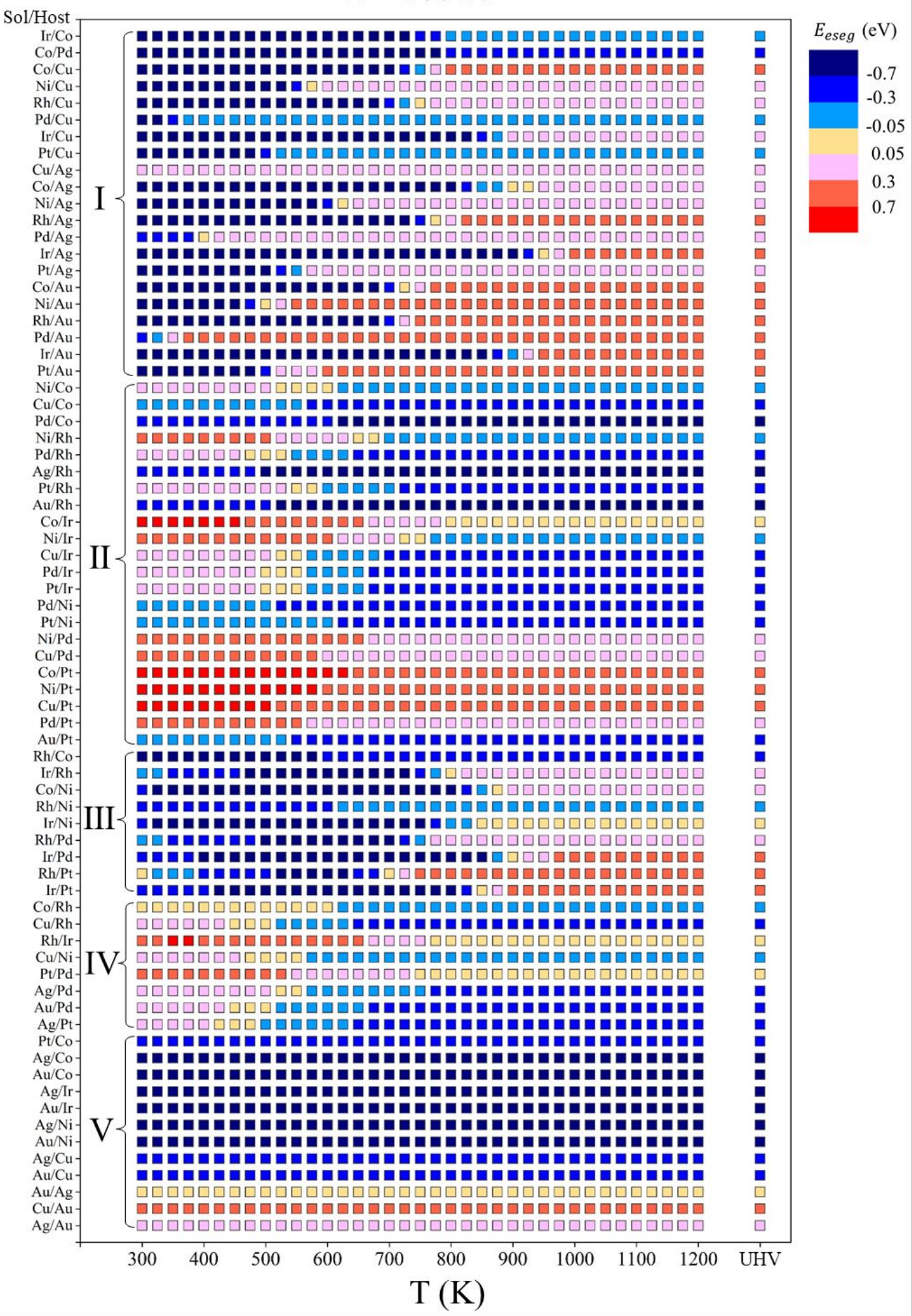

Figure S7. The environmental segregation energy $E_{\text {eseg }}$ of the 72 bimetallic alloys with the changing temperature under $100 \mathrm{PaCO}$, compared with the segregation energy $E_{\text {seg }}$ under UHV. The segregation trend is donated by color based on the value of $E_{\text {eseg }}$, and the corresponding value is labeled with the colorbar. 
Ag (host)
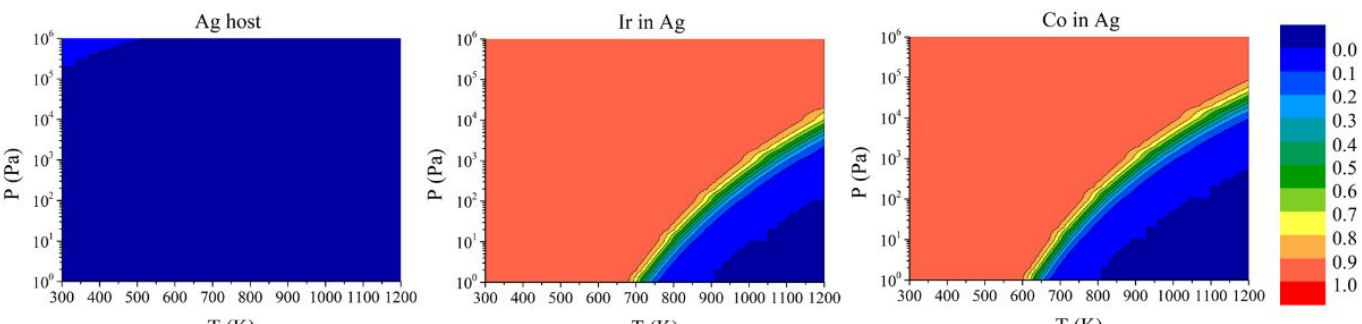

$\mathrm{T}(\mathrm{K})$

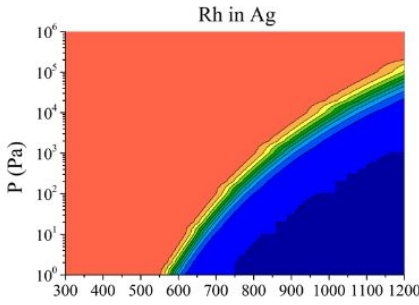

$\mathrm{T}(\mathrm{K})$

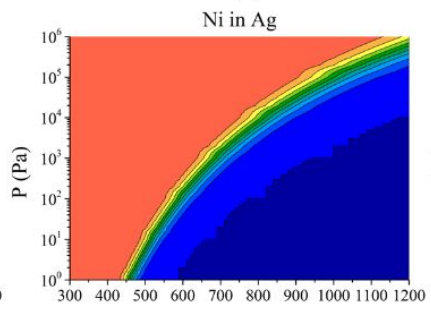

$\mathrm{T}(\mathrm{K})$

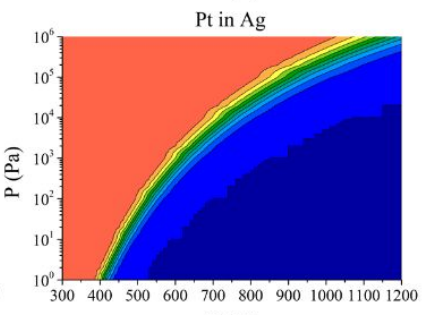

$\mathrm{Pd}$ in

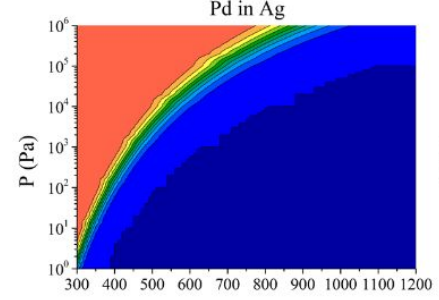

$\mathrm{T}(\mathrm{K})$

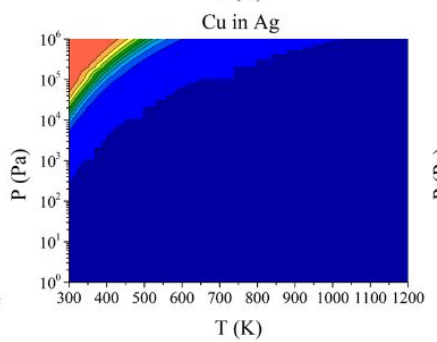

$\mathrm{T}(\mathrm{K})$

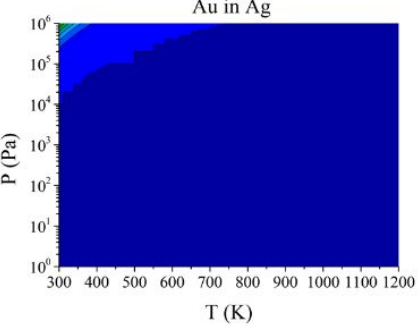

$\mathrm{Au}$ (host)
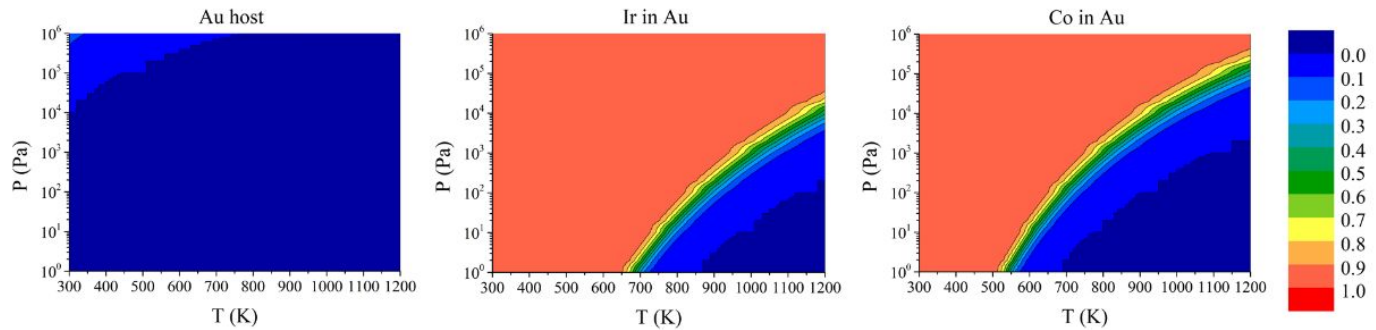

$\mathrm{Rh}$ in $\mathrm{Au}$
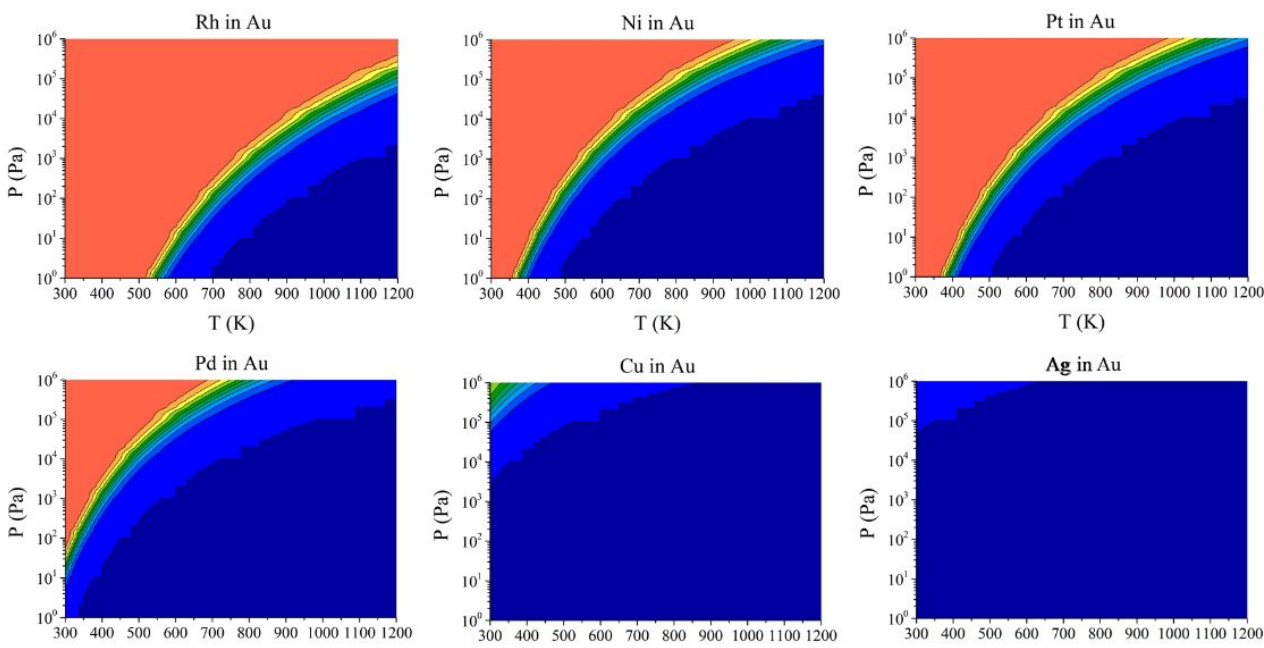

$\mathrm{T}$ (K)
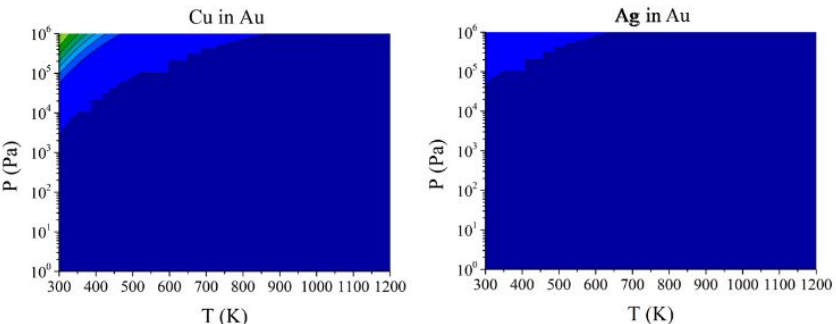


\section{$\mathrm{Cu}$ (host)}
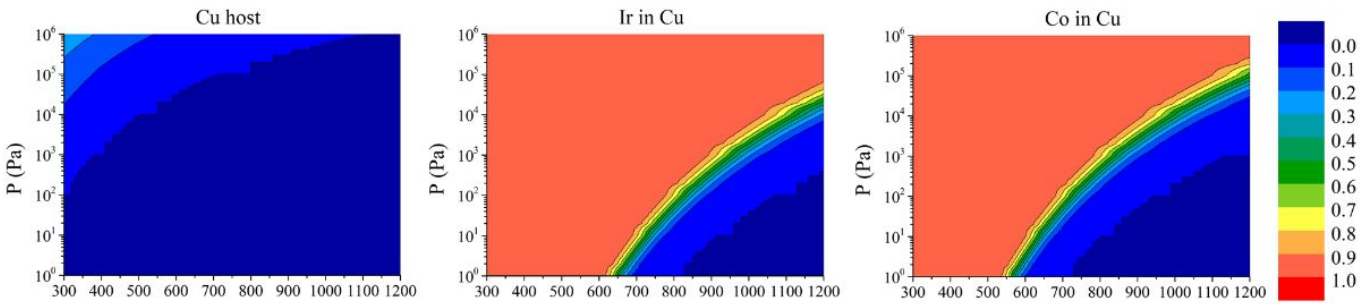

$\mathrm{T}(\mathrm{K})$

$\mathrm{T}(\mathrm{K})$

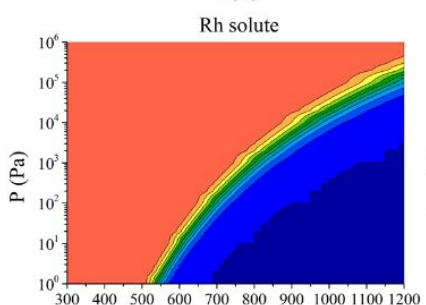

$\mathrm{Ni}$ in $\mathrm{Cu}$

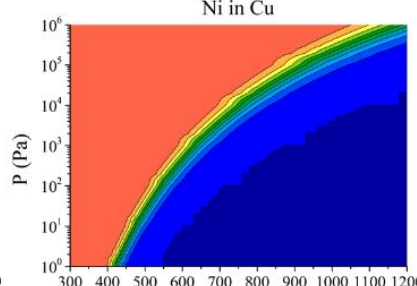

$\mathrm{T}(\mathrm{K})$

$\mathrm{Pd}$ in $\mathrm{Cu}$

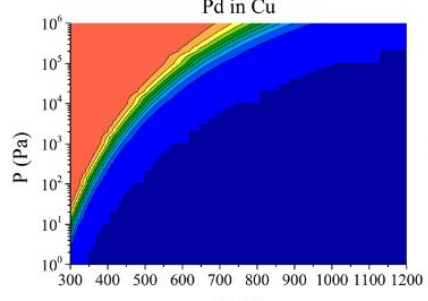

$\mathrm{Au}$ in $\mathrm{Cu}$

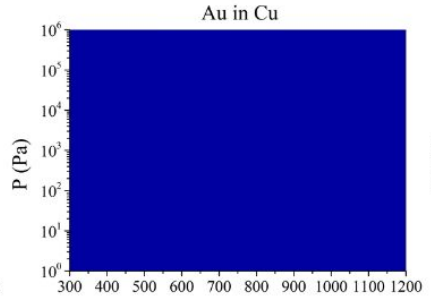

$\mathrm{T}$ (K)

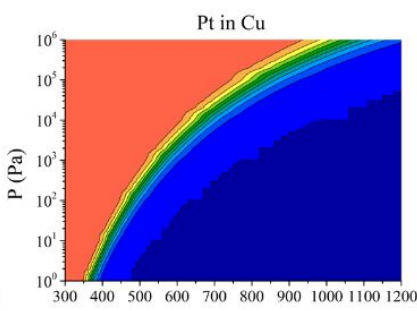

$\mathrm{T}(\mathrm{K})$

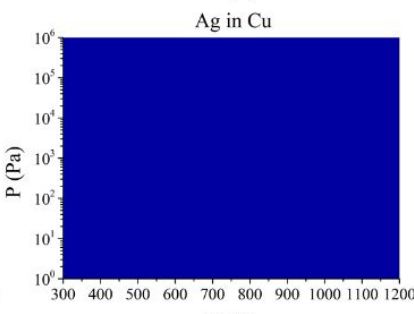

$\mathrm{T}(\mathrm{K})$

\section{Ir (host)}

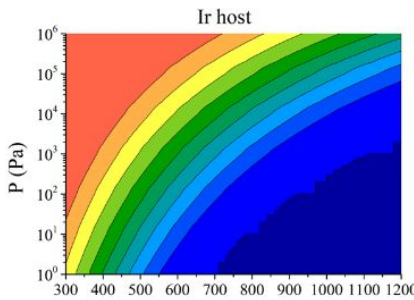

$\mathrm{T}(\mathrm{K})$

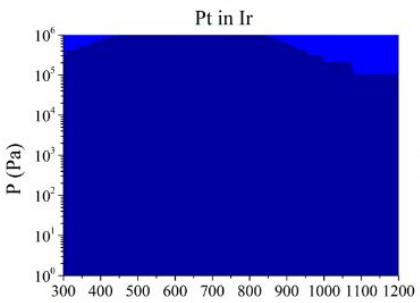

$\mathrm{T}(\mathrm{K})$
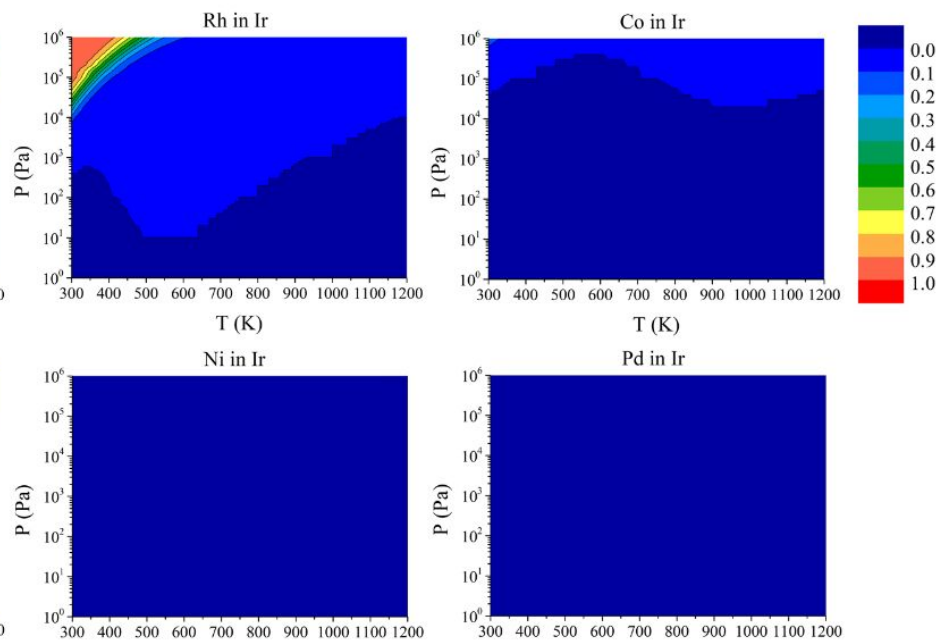

$\mathrm{T}(\mathrm{K})$

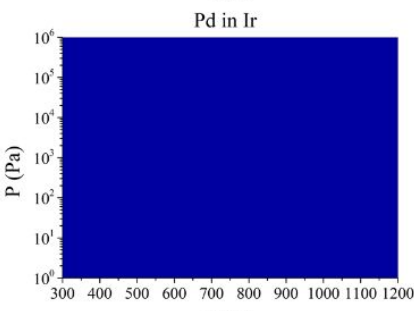

$\mathrm{T}$ (K)

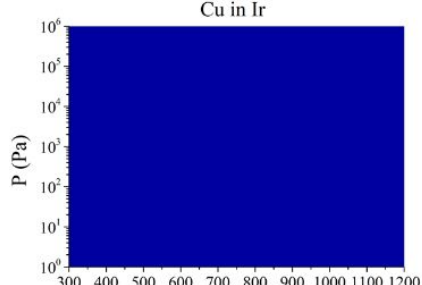

$\mathrm{T}(\mathrm{K})$

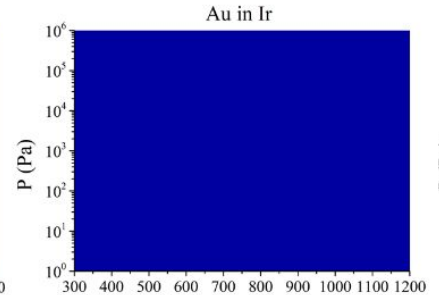

$\mathrm{T}(\mathrm{K})$

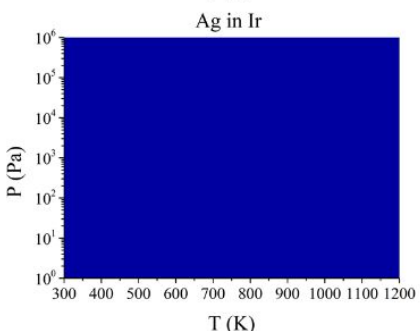




\section{Ni (host)}

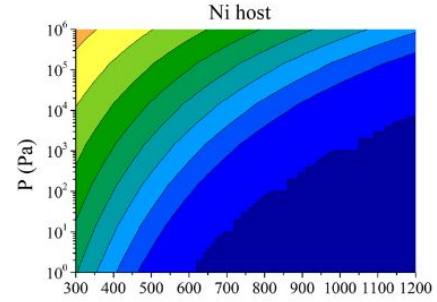

$\mathrm{T}(\mathrm{K})$

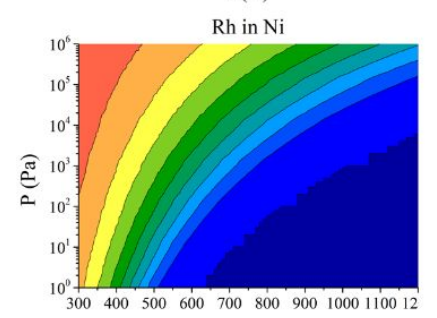

$\mathrm{T}(\mathrm{K})$

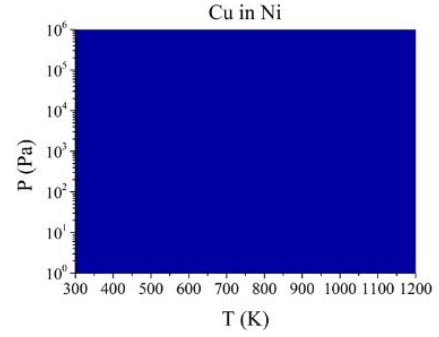

\section{Pd (host)}

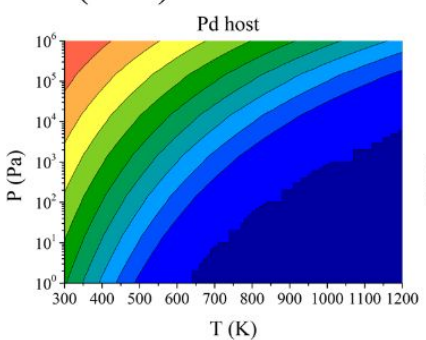

$\mathrm{Rh}$ in $\mathrm{Pd}$

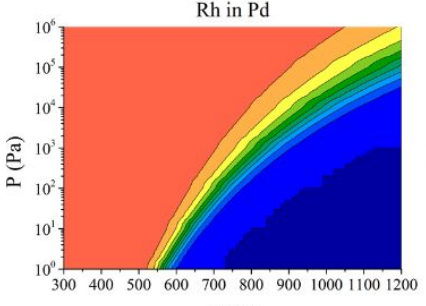

$\mathrm{T}(\mathrm{K})$

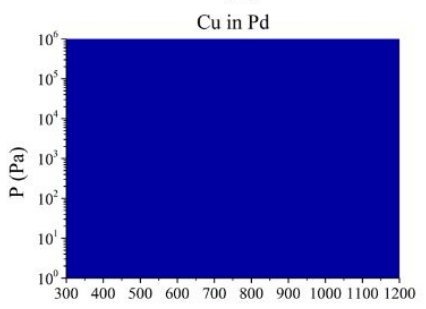

$\mathrm{T}(\mathrm{K})$
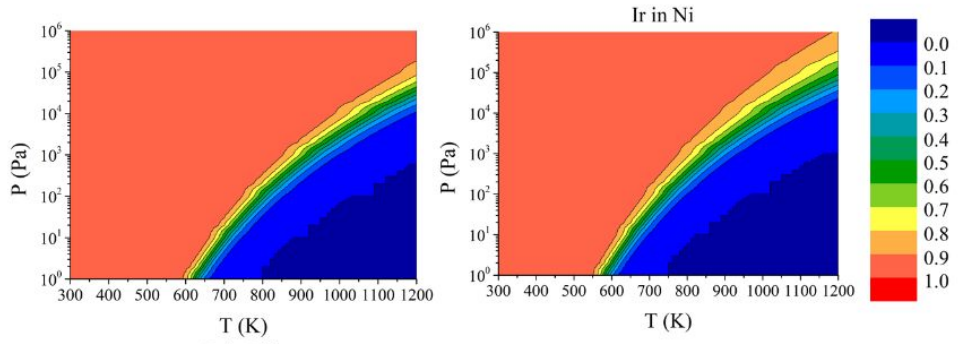

$\mathrm{Pd}$ in $\mathrm{Ni}$

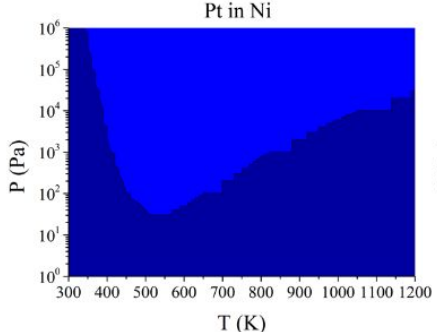

Au in Ni
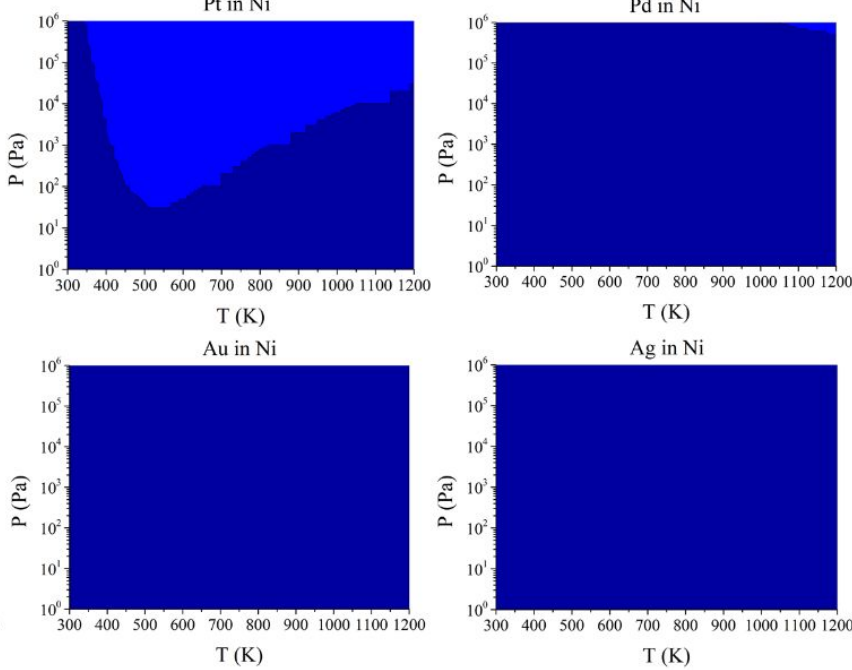

$\mathrm{Ag}$ in $\mathrm{Ni}$

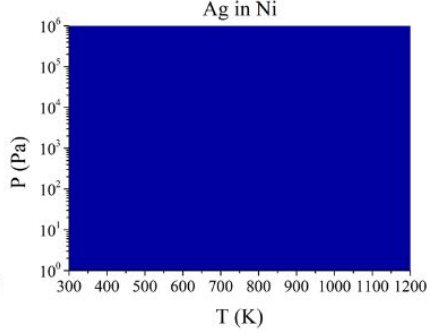

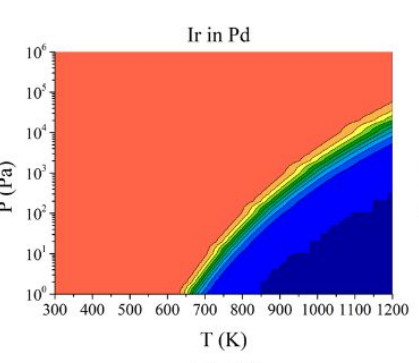

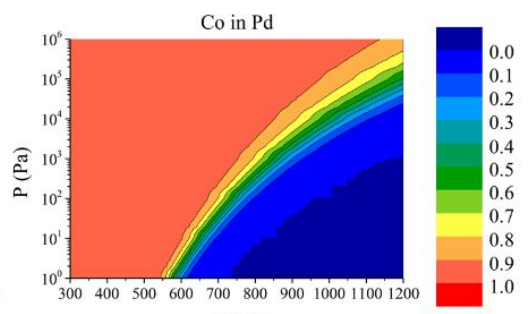

$\mathrm{T}$ (K)
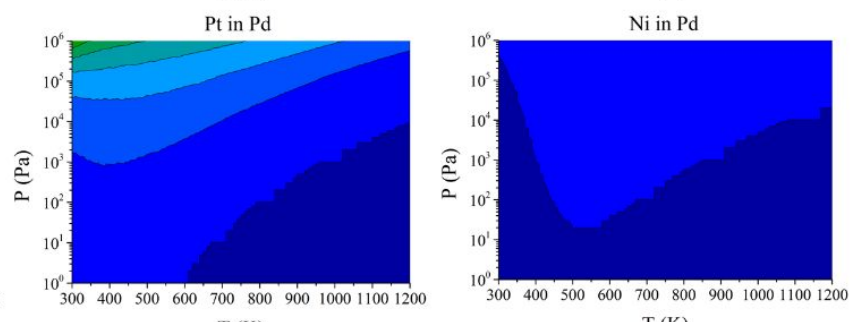

$\mathrm{T}(\mathrm{K})$

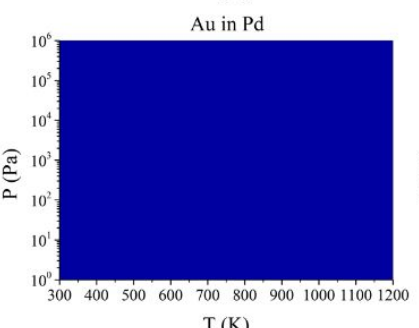

$\mathrm{T}(\mathrm{K})$

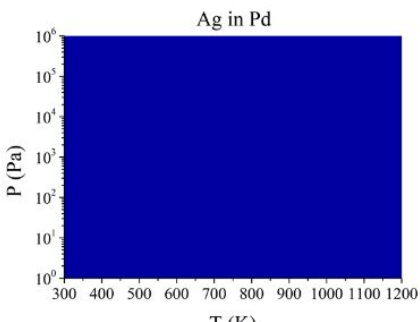

$\mathrm{T}(\mathrm{K})$ 


\section{Pt (host)}

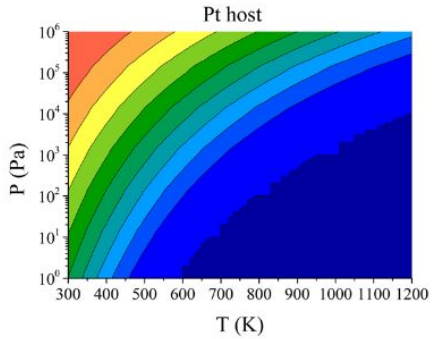

$\mathrm{Ni}$ in $\mathrm{Pt}$

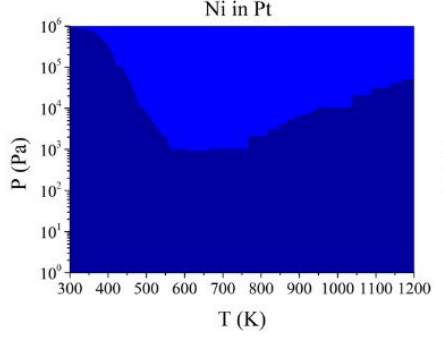

$\mathrm{Cu}$ in $\mathrm{Pt}$

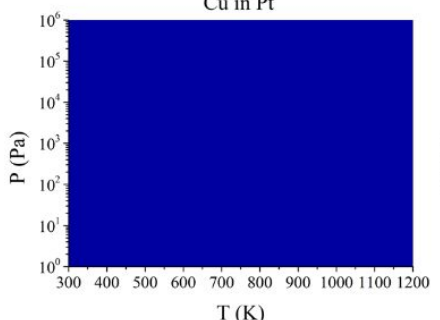

$\mathrm{T}(\mathrm{K})$
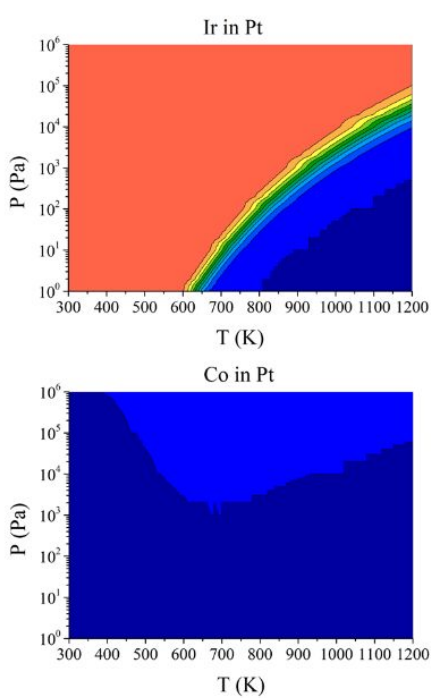

$\mathrm{Au}$ in $\mathrm{Pt}$

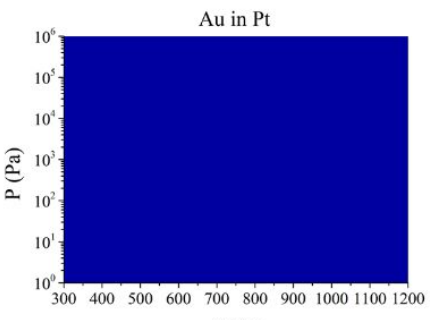

$\mathrm{T}(\mathrm{K})$

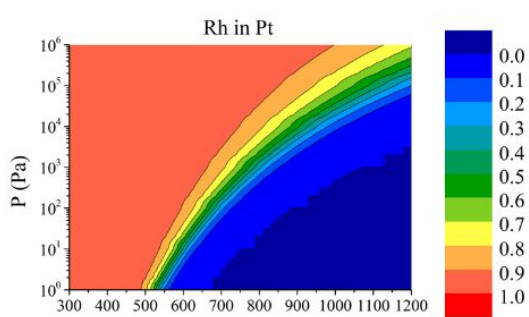

$\mathrm{T}(\mathrm{K})$

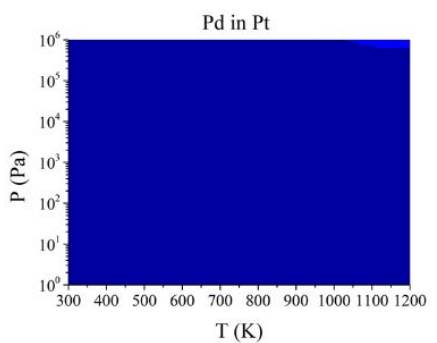

$\mathrm{Ag}$ in $\mathrm{Pt}$

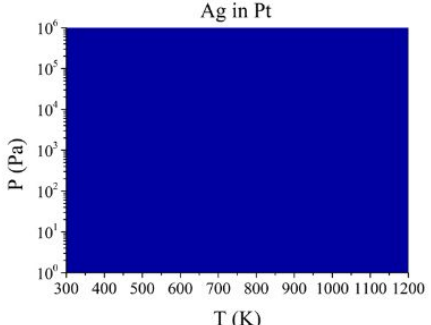

\section{$\mathrm{Rh}$ (host)}

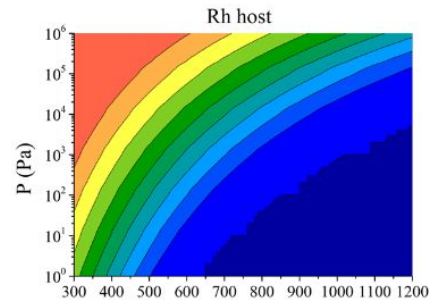

$\mathrm{T}(\mathrm{K})$

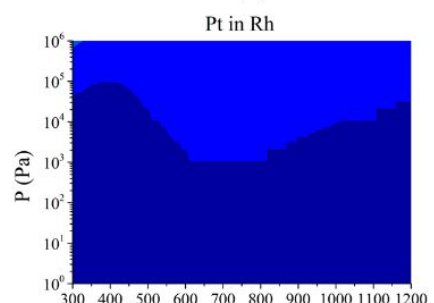

$\mathrm{T}(\mathrm{K})$

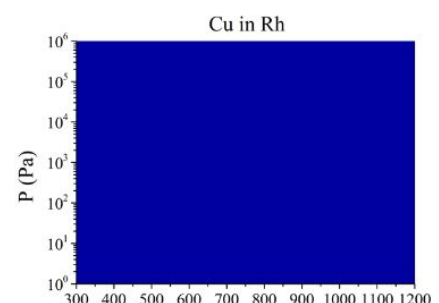

$\mathrm{T}(\mathrm{K})$

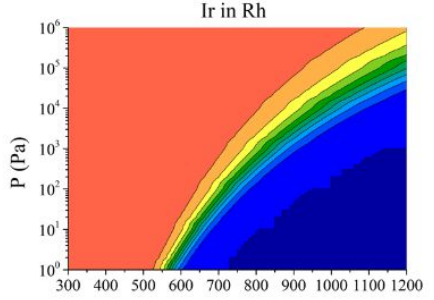

$\mathrm{T}(\mathrm{K})$

$\mathrm{Ni}$ in $\mathrm{Rh}$

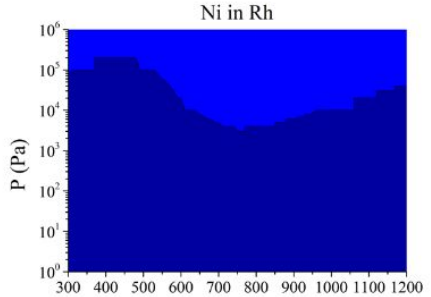

$\mathrm{T}(\mathrm{K})$

$\mathrm{Au}$ in Rh

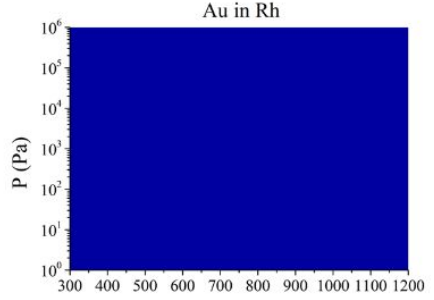

$\mathrm{T}(\mathrm{K})$

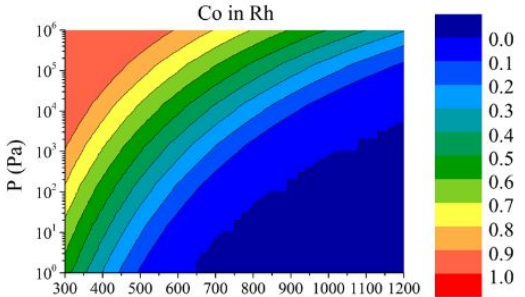

$\mathrm{T}(\mathrm{K})$

$\mathrm{Pd}$ in $\mathrm{Rh}$

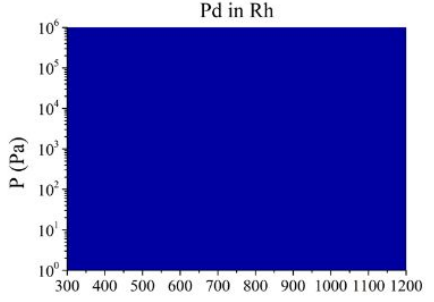

$\mathrm{T}(\mathrm{K})$

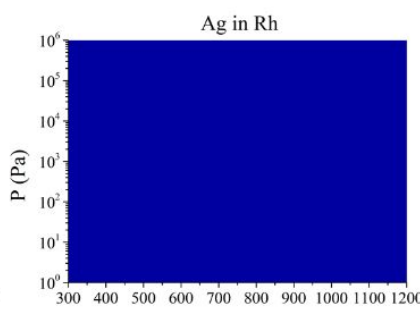

$\mathrm{T}(\mathrm{K})$ 


\section{Co (host)}
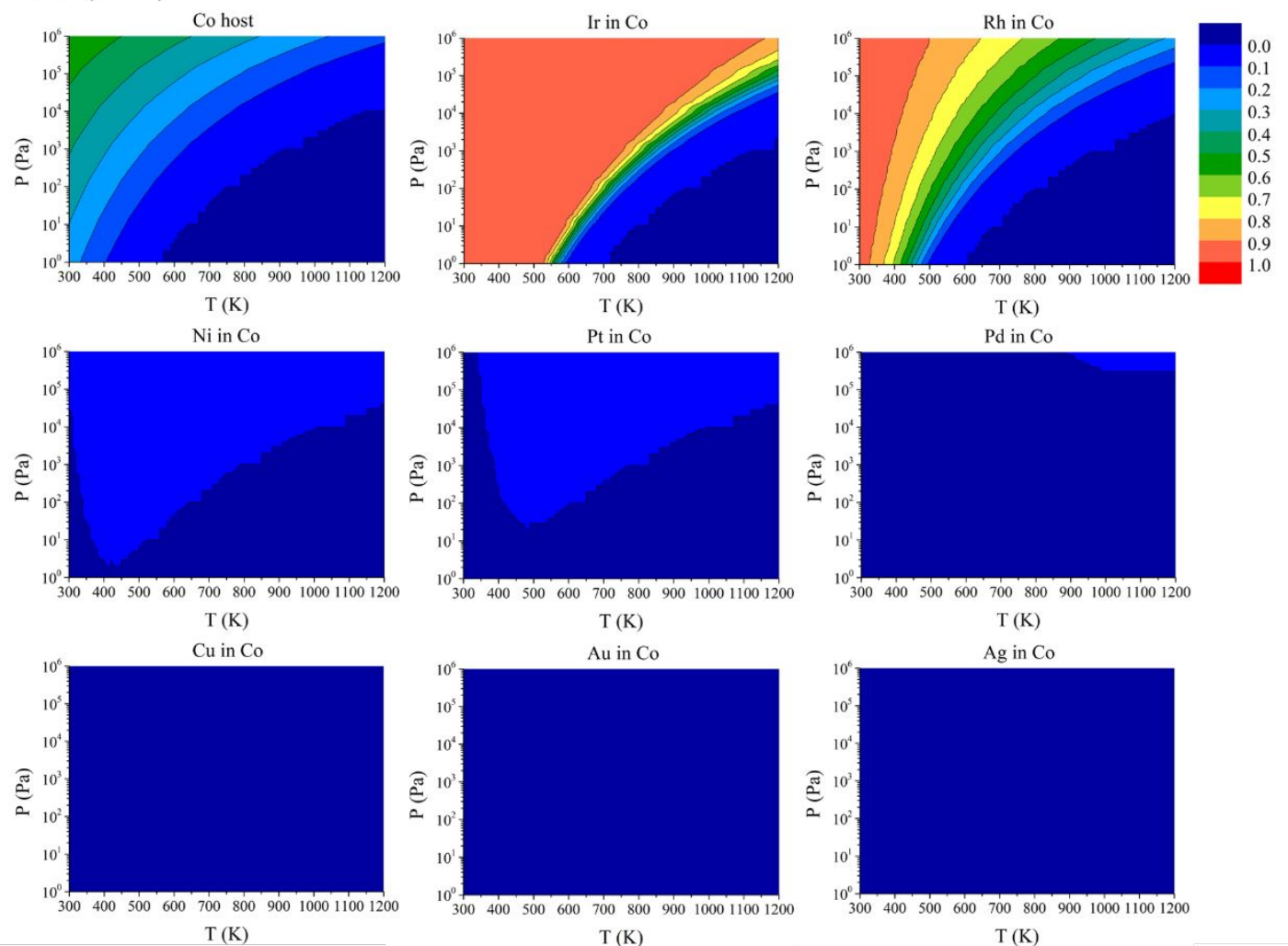

Figure S8. Contour plots of the CO coverage on host $\left(\theta_{\text {host }}\right)$ and solute $\left(\theta_{\text {sol }}\right)$ of 72 combinations of 9 transition metals as functions of temperature and $\mathrm{CO}$ pressure. The value of the coverage is denoted by colors, and the corresponding value is labeled with the colorbar. The phase graph of $\theta_{\text {host }}$ is titled by Metal host, and the phase graph of $\theta_{\text {sol }}$ is titled by Solute in Host. 